\title{
Review \\ Elastography-A Bona Fide Non-Invasive Method for Assessing Non-Alcoholic Fatty Liver Disease in Children
}

\author{
Cristina Oana Mărginean ${ }^{1} \mathbb{1}$, Lorena Elena Meliț ${ }^{1, *}$ and Maria Oana Săsăran ${ }^{2}$ \\ 1 Department of Pediatrics I, George Emil Palade University of Medicine, Pharmacy, Science, and Technology of \\ Târgu Mures, Gheorghe Marinescu Street no 38, 540136 Transylvania, Romania; marginean.oana@gmail.com \\ 2 Department of Pediatrics III, George Emil Palade University of Medicine, Pharmacy, Science, and Technology \\ of Târgu Mureș, Gheorghe Marinescu Street no 38, 540136 Transylvania, Romania; oanam93@yahoo.com \\ * Correspondence: lory_chimista89@yahoo.com; Tel.: +40-742-984744
}

Citation: Mărginean, C.O.;

Meliț, L.E.; Săsăran, M.O.

Elastography-A Bona Fide

Non-Invasive Method for Assessing Non-Alcoholic Fatty Liver Disease in Children. Appl. Sci. 2021, 11, 3240. https://doi.org/10.3390/ app11073240

Academic Editor: Francisco Arrebola

Received: 28 February 2021

Accepted: 1 April 2021

Published: 4 April 2021

Publisher's Note: MDPI stays neutral with regard to jurisdictional claims in published maps and institutional affiliations.

Copyright: (c) 2021 by the authors. Licensee MDPI, Basel, Switzerland. This article is an open access article distributed under the terms and conditions of the Creative Commons Attribution (CC BY) license (https:// creativecommons.org/licenses/by/ $4.0 /)$.

\begin{abstract}
Pediatric obesity has become a major public health problem worldwide, resulting in a wide spectrum of systemic complications. Liver disease associated with obesity, also known as nonalcoholic fatty liver disease (NAFLD), is currently the most common chronic liver condition in children. Therefore, its timely and proper diagnosis is essential for preventing further development of cirrhosis. Multiple studies focused on identifying the most accurate non-invasive diagnostic method for liver fibrosis or cirrhosis. Although liver biopsy remains the gold-standard in terms of this hepatopathy, elastography methods emerged as a relatively reliable alternative to liver biopsy. Thus, recent studies revealed the great importance of these non-invasive methods not only in diagnosing pediatric NAFLD, but also in its staging. MRE is commonly considered to have a greater accuracy than ultrasound-based elastography methods, but with lower availability and higher costs. Ultrasoundbased elastography methods (transient elastography (TE), p-SWE, and 2-dimensional shear wave elastography (2D-SWE)) were proved to have similar accuracy in NAFLD staging. Nevertheless, multiple confounding factors account for potential challenges when using elastography for liver stiffness measurement, such as age, obesity itself (i.e., BMI), transaminase levels, or portal flow. A potential solution for facing these challenges might be represented by a complex approach based on the combination between elastography, clinical and laboratory findings. Although the studies that assessed the role of elastography in pediatric NAFLD staging are scarce, the current knowledge underlines a crucial role of these techniques taking into account their ability to distinguish between fibrosis degrees, their non-invasive patterns, lower costs and side effects when compared to liver biopsy. Therefore, elastography might become a cornerstone in staging pediatric NAFLD.
\end{abstract}

Keywords: elastography; children; nonalcoholic fatty liver disease

\section{Introduction}

Childhood obesity is a continuous emerging burden worldwide. According to the World Health Organization reports from 2018, pediatric overweight and obesity represent two major public health problems affecting over 40 million children aged under 5 years [1]. Both conditions consist of excessive fat accumulation and carry a wide-spectrum of associated complications. Although genetic susceptibility was proven to be a mandatory factor in the development of obesity [2], the contribution of environmental factors in this process is a sine qua non condition. Moreover, it was underlined that overweight is not only a preliminary step in the development of obesity, but it might represent an optimal, essential opportunity of self-awareness for further hindering the occurrence of obesity [3]. A wide-spectrum of conditions were defined as obesity-associated complications such as cardiovascular, hepatic, or metabolic disorders [4]. Most of these complications were related to the well-documented systemic inflammatory status encountered in patients with obesity [5,6]. 
Liver disease in the setting of obesity is currently acknowledged as one of the most frequent complications of children with this nutritional disorder. Thus, non-alcoholic fatty liver disease (NAFLD) was reported in approximately $50 \%$ of children with obesity, being considered the most common pediatric chronic liver disease, with an incidence ranging between 5 and 17\% among children from Western countries [7]. NAFLD, defined as accumulation of fat in the liver, is generally a silent, potentially reversible condition, but it might also progress into a more severe form, i.e., non-alcoholic steatohepatitis (NASH) associating steatosis, inflammation and cellular injury with or without fibrosis [8], with an increased the risk for cirrhosis and end-stage liver disease $[9,10]$. The gold-standard in providing an accurate diagnosis and staging of NAFLD is undoubtedly liver biopsy, which also allows a proper assessment of other hepatic conditions. Nevertheless, this procedure carries multiple risks in children and parents' refusal is a major hindrance for this approach in young ages. Therefore, the early diagnosis and staging of NAFLD might represent a real challenge in children since no free national screening programs similar to other conditions are currently available [11,12]. A complex approach consisting of the assessment of several laboratory parameters combined with different imaging tools represents an alternative for liver biopsy. Most of the studies sustain that elevated liver transaminases represent a common finding associated with liver disease in children with obesity [5]. Taking into account their fluctuations over time and even their normal levels in children with NAFLD, or even NASH, their role as single parameter in diagnosing this hepatic condition is doubtable [13]. The American Association for the Study of Liver Disease (AASLD) recommends the use of two algorithms, FIB-4 and NFS, for the assessment of liver fibrosis based on routine clinical and laboratory parameters, which seem to be useful in predicting advanced hepatic cirrhosis or fibrosis [14]. Thus, FIB-4 takes into account the age, platelets count, aspartate aminotransferase (AST), and alanine aminotransferase, and it was proved to be useful for the stratification of NAFLD patients differentiating between those with advanced fibrosis versus none [15-17]. NFS is an even more complex algorithm including not only the age, the platelets, and AST / ALT ration, but also BMI, albumin levels, and the assessment of glucose tolerance/diabetes, representing a reliable alternative for liver biopsy [8]. Studies performed on children and adolescents with obesity pointed out higher levels of AST/platelets ratio index (APRI) in these patients, but failed in identifying a correlation with liver stiffness $[18,19]$. In addition to liver transaminases, bilirubin, lipid profile parameters, fasting glucose, and insulin are also useful for diagnosing fatty liver disease in patients with metabolic syndrome [13]. A clear bidirectional interrelation has been stated between NAFLD and metabolic syndrome, whose components (e.g., type 2 diabetes mellitus, obesity, hypertension, dyslipidemia) additionally increase the risk of developing NAFLD [20-23]. Furthermore, NASH carries higher rates of both morbidity and mortality increasing the risk of cirrhosis and hepatocellular carcinoma [24], with a higher mortality as compared to isolated or simple steatosis [25]. Taking into account the current era of pediatric obesity, the early detection and staging of NAFLD based on a more complex non-invasive approach including clinical, laboratory, and elastography parameters might contribute to the effective prevention of further irreversible hepatic lesions and decrease mortality during adulthood.

The aim of this review was to assess the role of elastography in pediatric NAFLD staging, as well as identifying its potential limitations and challenges in this age group.

\section{Current Elastography Methods}

Elastography methods are defined by the non-invasive assessment of tissue elasticity and its mechanical properties resulting from the application of external forces. Two major terms that are commonly confounded in practice must be differentiated: tissue elasticity, i.e., the tissue ability to deform and resume its normal shape in the setting of an applied stress dependently of tissue stiffness, the second term, which indicates tissue composition and structure [26]. Thus, when referring to elastography, the term liver stiffness seems to be more appropriate. 
Liver elastography has gained a lot of interest in the context of NAFLD, a current global public health problem in all age groups. Thus, liver elastography aims to objectively characterize diffuse liver disease and it might reflect pathologic processes such as fibrosis, inflammation or congestion [27-30]. Taking into account the increased rates of both morbidity and mortality in patients with diffuse liver disease [31], a proper management is essential for the best outcome in these patients. Furthermore, the management depends mostly on the accurate staging of liver fibrosis. Liver elastography seems to be a promising diagnostic tool in the assessment of liver fibrosis irrespectively of the age and type of chronic liver disease.

Current elastography methods for liver assessment encompass magnetic resonance elastography (MRE), and three main ultrasound-based elastography techniques, i.e., transient elastography (TE, Figure 1), acoustic radiation force impulse (ARFI) divided into point shear wave elastography (p-SWE), and 2-dimensional shear wave elastography (2D SWE, Figure 2), and strain elastography. The latter one is not used for liver stiffness measurement and therefore we will not focus on its description since it does not fulfill the aim of this review. Liver fibrosis is a dynamic process consisting of excessive extracellular matrix accumulation as a result to injury and inflammation, followed by degradation of this excessive matrix and consequent remodeling [25]. Fibroblasts and myofibroblasts also contribute to hepatic fibrosis [25]. Independently of its continuous dynamics, at some point hepatic fibrosis exceeds degradation, leading to cirrhosis and related-changes in vascular architecture. Moreover, both excessive extracellular matrix in the setting of liver fibrosis and vascular architecture changes result in increased liver stiffness [25].

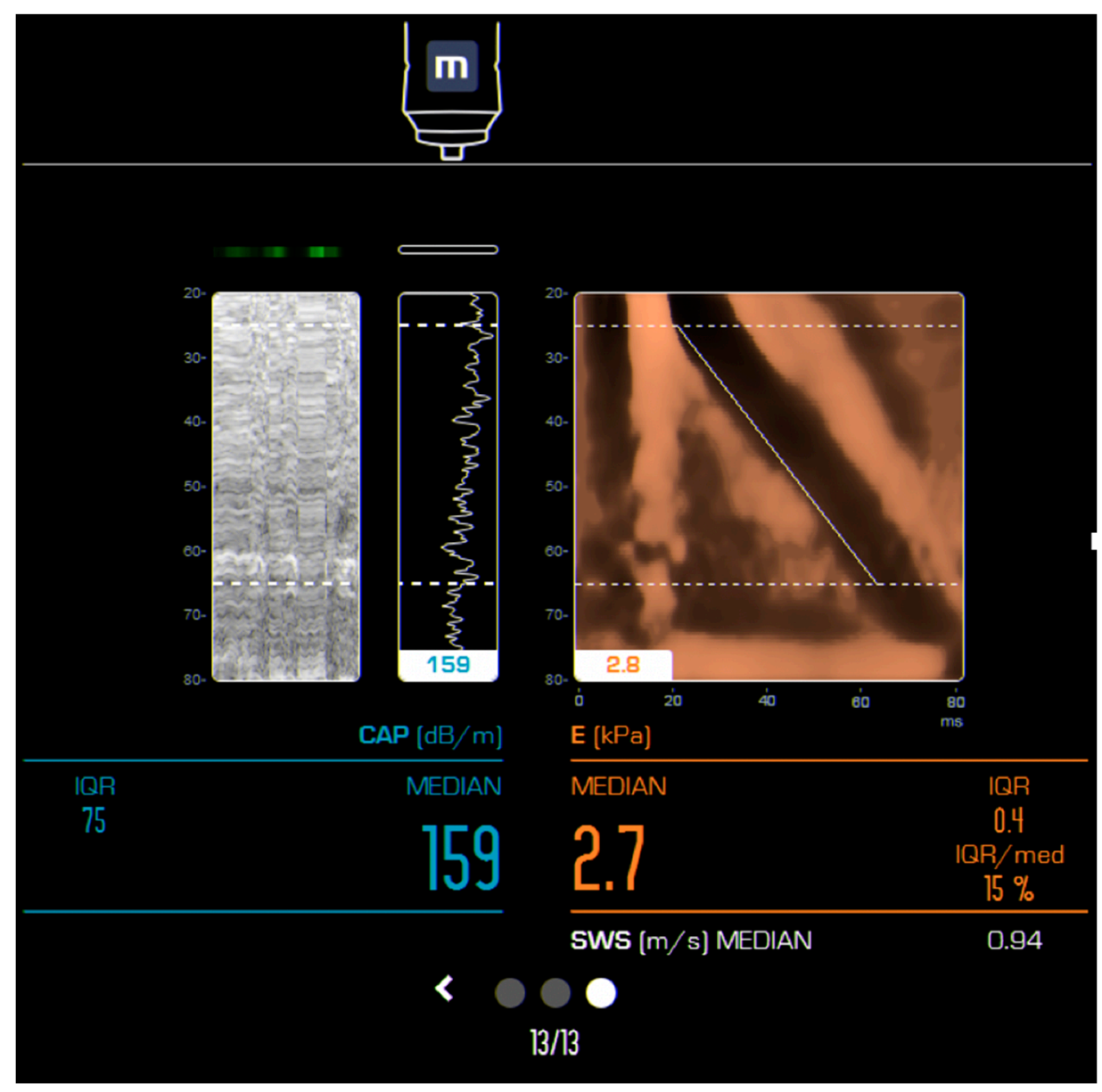

Figure 1. Liver transient elastography (TE) in normal weight healthy children. 


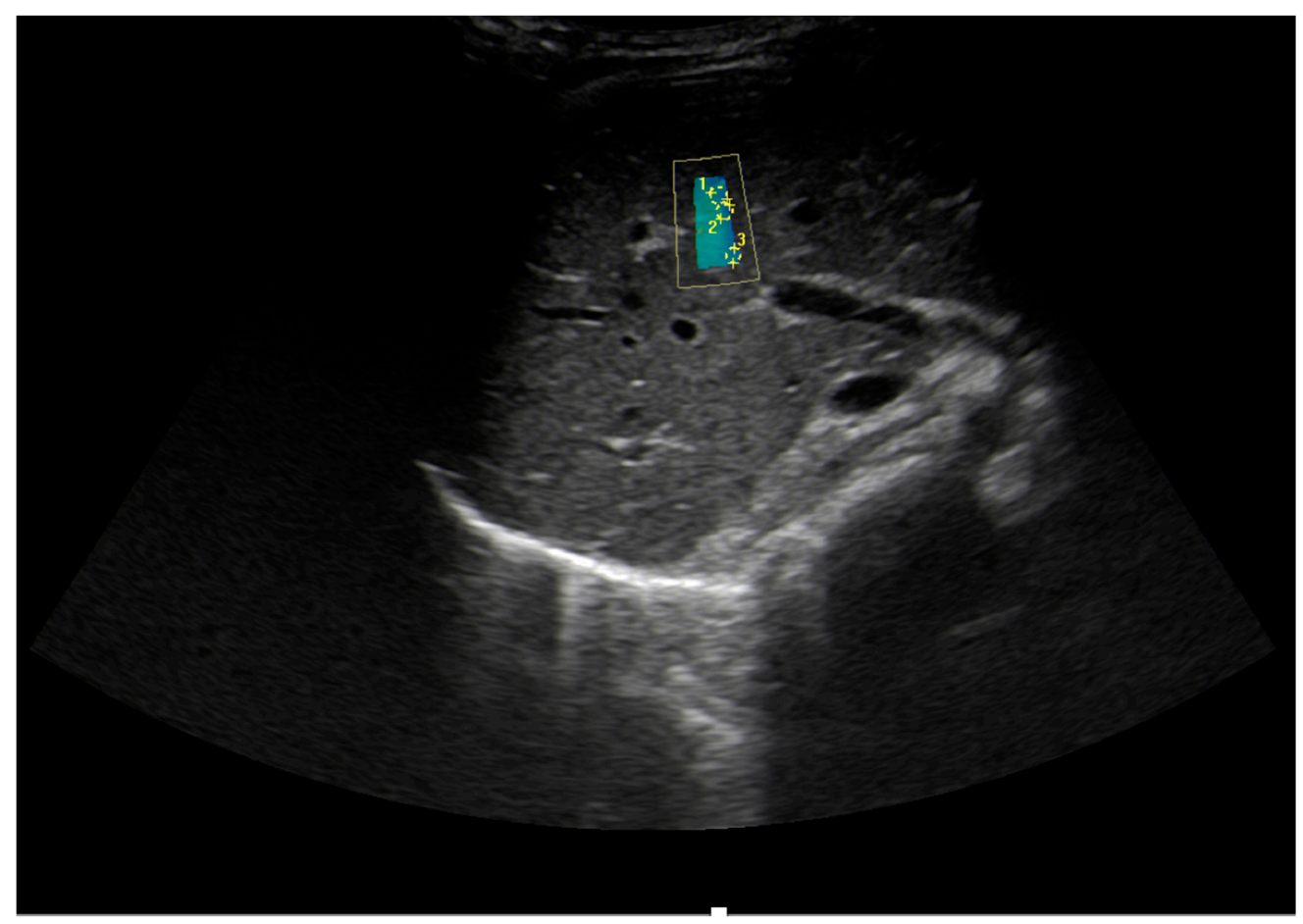

Figure 2. Liver 2-dimensional shear wave elastography(2D-SWE) in normal weight healthy children.

MRE of liver uses mechanically generated shear waves, which are propagated into the liver and their images are obtained using a modified phase contrast MRI sequence, further converted into tissue stiffness maps or elastograms based on an inversion algorithm [32,33]. It is important to mention that the propagation of these shear waves occurs faster in stiffer tissue than in softer tissue, i.e., in cirrhotic tissue as compared to normal liver. Clinical liver MRE set up usually consists of an active driver, a passive driver positioned in the inferior part of the right chest wall closer to the liver, and a 25-foot-long plastic tube connecting these drivers. The active driver is represented by an acoustic driving system that generates $60 \mathrm{~Hz}$ shear waves in tissue from outside the scanner room. The passive driver is activated as a result of varying acoustic pressure triggered from the active driver via the plastic tube. Patients must rest in a supine position during the exam. Tissue displacement caused by the propagation of shear waves is determined by a modified phase contrast imaging sequence, which uses different conventional MR sequences, such as gradient recalled echo, echoplanar imaging, spin echo, or balanced steady state free precision. MRE has the capacity to spatially map and quantify displacement patterns, which are useful for the calculation of certain mechanical characteristics related to wave propagation. Several MRE algorithms are available for the inversion of wave information into stiffness maps such as direct inversion of differential equations of motion, spatial frequency measurement, or iterative method based on the finite element model. These algorithms are used for measuring an important mechanical tissue characteristic, i.e., 'the magnitude of the complex shear modulus' accounting for both elasticity and viscosity, expressed in kilopascals [34-36].

It is well-documented that MRE is more accurate for both detecting and staging of liver fibrosis [32,37] as compared to ultrasound-based elastography methods, but with definitely higher associated costs. MRE technical performance reaches approximately 95\% and the most common cause of failure is iron overload [25]. Additionally, a study that assessed 781 liver MREs pointed out other independent factors related to failure, among which were ascites and increased body mass index [38]. Nevertheless, a more recent study performed on 71 healthy pediatric volunteers revealed a mean liver stiffness value of $2.1 \mathrm{kPa}$, pointing out that sex, age, or BMI had no impact on liver stiffness measurement [34]. Conflicting results might be explained by technical or platform-related differences in terms 
of strength, driver frequency used for MRE, MR scanner vendor, or they might reflect the differences between the populations included in the study [34]. Liver thresholds for MRE defined for healthy children differ from those in healthy adults [39]. Thus, Etchell et al. revealed that healthy children present lower liver stiffness values as compared to healthy adults [40]. These findings came in contradiction to those of Sawh et al., who recently found that normal liver stiffness values were higher in children than previously reported for adults [33]. In terms of liver fibrosis, different studies pointed out that the cut-off values range between 2.4-2.93 $\mathrm{kPa}$ [41-45]. A strong correlation has been identified between MRE liver stiffness measurements and the amount of fibrosis in the liver biopsy samples suggesting that MRE has the same accuracy as biopsy for liver fibrosis staging [46]. The accuracy of MRE for detecting liver fibrosis increases with the stage of fibrosis, but with an excellent overall performance [37]. Recent studies underlined that MRE has only modest accuracy in distinguish between NASH and simple steatosis [47-49], a large study involving pediatric patients pointing out that liver fat may express a mild softening effect in the setting of MRE assessment [50]. Therefore, a considerably improved alternative method consists of a comprehensive liver MRI study defined by fat quantification, detection of inflammation and staging of liver fibrosis [51], with an obvious higher accuracy, but considerable associated costs. Nevertheless, Chen et al. pointed out that MRE has a $94 \%$ sensitivity and a $73 \%$ specificity with an accuracy of 0.93 in discriminating between simple steatosis and NASH [45]. In terms of NAFLD, the MRE specificity and sensitivity rates were proven to be $93 \%$ and $85 \%$ in detecting advanced fibrosis [52]. The most important findings regarding MRE in children are summarized in Table 1. Altogether, ultrasound based elastography methods might be a more available option with lower associated costs and similar result.

The shear wave-based methods, i.e., TE and ARFI, assess the speed of these waves in tissue depending on tissue stiffness, the waves being triggered by an external mechanical force in case of TE and the push pulse of a focused ultrasound beam in case of ARFI [53]. TE is a 1D technique provided by the FibroScan system (Echosens, Paris, France) and its latest version uses the controlled attenuation parameter (CAP) tool in order to measure the decrease in amplitude of ultrasound signal in the liver. The results range between $100-400 \mathrm{~dB} / \mathrm{m}$ depending on the amount of fat tissue within the liver. Three types of probes are available for this system: the $S$ probe, designed for children since their thoracic diameters is $<75 \mathrm{~cm}$, for measurements between $1.5-5 \mathrm{~cm}$, with a frequency of $5.0 \mathrm{MHz}$; the $\mathrm{M}$ probe designed for measurements up to $6.5 \mathrm{~cm}$ from the skin, with a frequency of 3.5 $\mathrm{MHz}$; and the XL probe designed for a distance $>2.5 \mathrm{~cm}$ between the skin and liver capsule, with a frequency of $2.5 \mathrm{MHz}$, for measurements ranging between $3.5-7.5 \mathrm{~cm}$. As of today, CAP has the ability to display only valid measurements, being computed as a result of the ultrasound signals used for acquiring liver stiffness measurements [35]. 
Table 1. Magnetic resonance elastography (MRE) values in normal weight and obese children.

\begin{tabular}{|c|c|c|c|c|c|}
\hline \multirow[b]{2}{*}{ Author, Year, and Country } & \multirow{2}{*}{$\begin{array}{l}\text { Study Type/No of } \\
\text { Patients }\end{array}$} & \multirow{2}{*}{$\begin{array}{c}\text { Age (Years) } \\
\text { Mean/Median * }\end{array}$} & \multicolumn{2}{|c|}{ MRE (KPa) } & \multirow[b]{2}{*}{ Observations } \\
\hline & & & $\begin{array}{l}\text { Normal Weight Children } \\
\text { Mean/Median* }\end{array}$ & $\begin{array}{l}\text { NAFLD/NASH Children } \\
\text { Mean/Median * }\end{array}$ & \\
\hline Sawh et al., 2020, USA [33] & Prospective/81 & $12.6 \pm 2.6$ & $2.45 \pm 0.35$ & - & $\begin{array}{l}\text { The values are significant higher than in } \\
\text { adults }(2.10 \pm 0.23 \mathrm{kPa})(p<0.001)\end{array}$ \\
\hline Trout et al., 2020, USA [34] & Prospective/71 & $12 *$ & $2.1 \pm 1.96$ & - & $\begin{array}{l}\text { P95 for normal liver stiffness was } 2.8 \mathrm{kPa} \text {. } \\
\text { Liver stiffness was independent of sex, age, } \\
\text { or BMI }\end{array}$ \\
\hline Joshi et al., 2018, USA [50] & Prospective/202 & $13.4 \pm 2.9$ & - & $2.6 \pm 0.6$ & $\begin{array}{l}\text { Relationships between stiffness, and organ } \\
\text { volume and some patient-specific factors, } \\
\text { including sex, age, BMI, serum ALT, and } \\
\text { diabetic status }\end{array}$ \\
\hline Trout et al., 2018, USA [55] & Prospective/86 & $14.2 *$ & $\begin{array}{l}\text { F0: } 2.90 \pm 0.87 ; \mathrm{F} 1: 2.41 \pm \\
0.51 ; \mathrm{F} 2: 3.64 \pm 1.12 ; \mathrm{F} 3: 4.55 \\
\quad \pm 1.68 ; \mathrm{F} 4: 4.68 \pm 1.32\end{array}$ & $\begin{array}{l}\text { F0: } 2.68 \pm 0.31 ; \mathrm{F} 1: 3.04 \pm \\
\text { 0.63; F2: } 2.71 \pm 0.59 ; \mathrm{F} 3: 7.43 \\
\quad \pm 2.68 ; \mathrm{F} 4 \text { not aplicable }\end{array}$ & $\begin{array}{l}\text { MR elastography performs significantly } \\
\text { better for distinguishing stage } 0-1 \text { versus } \\
\text { stage } 2 \text { or higher fibrosis in patients without } \\
\text { steatosis than in those with steatosis. }\end{array}$ \\
\hline Joshi et al., 2017, USA [56] & Retrospective/372 & $12.6 \pm 3.7$ & - & $2.94 \pm 1.11 \mathrm{kPa}$ & Mean patient BMI was $29.4 \pm 10.1 \mathrm{~kg} / \mathrm{m}^{2}$ \\
\hline Schwimmer et al., 2017, USA [57] & Prospective/90 & $13.1 \pm 2.4$ & - & $2.35 \mathrm{kPa}$ & $\begin{array}{l}\text { Correlation with fibrosis (by biopsy) was } \\
72.2 \%\end{array}$ \\
\hline Etchell et al., 2017, Australia [40] & Prospective/24 & $5-18$ & - & $\begin{array}{c}\text { Children: At } 28 \mathrm{~Hz}: 1.2 \pm \\
0.2 \text { /At } 56 \text { Hz: } 2.2 \pm 0.3 / \text { At } 84 \\
\text { Hz: At } 5.6 \pm 0.8 \\
\text { Adolescents: At } 28 \mathrm{~Hz}: 1.3 \pm \\
0.3 \text { /At } 56 \mathrm{~Hz}: 2.2 \pm 0.2 \text { /At } 84 \\
\text { Hz: } 6.5 \pm 1.2\end{array}$ & $\begin{array}{l}\text { Liver stiffness values are lower and vary less } \\
\text { with frequency in children and adolescents } \\
\text { than in adults. }\end{array}$ \\
\hline Xanthakos et al., 2014, USA [58] & Prospective/35 & 13 * & - & $\begin{array}{c}\mathrm{F} 1: 2.2 \mathrm{kPa} ; \mathrm{F} 3: 3.6 \mathrm{kPa} ; \mathrm{F} 4: \\
4.9 \mathrm{kPa}\end{array}$ & $\begin{array}{l}\text { Cut-off }=2.71 \mathrm{kPa}-8 \% \text { sensitivity, } 85 \% \\
\text { specificity for F2 with an AUROC of } 0.92 \\
(95 \% \text { CI, } 0.79-1.00 ; p=0.02)\end{array}$ \\
\hline
\end{tabular}

Legend: MRE—magnetic resonance elastography, y-years; * Mean age calculated from mean of the three age groups in the study. 
ARFI techniques are available on both linear and curvilinear transducers and as aforementioned, they rely on the generation of shear waves from the push pulse of the ultrasound beam [59]. In practice, an initial push pulse is applied to the tissue, inducing shear waves perpendicular to the ultrasound beam. The speed of the shear waves propagating through the tissue are estimated using B-mode imaging tracking, and it is proportional to tissue stiffness. Using these methods, liver stiffness can be expressed in $\mathrm{m} / \mathrm{s}$ displaying the speed of the shear wave through the tissue, or in $\mathrm{kPa}$, based on the Young's modulus. 2-dimensional shear wave elastography (2D-SWE) uses a large field of view with pixel color coding of the stiffness values, while p-SWE is based on the assessment of a fixed region of interest (ROI) of approximately $1 \mathrm{~mL}$. Regarding the actual technique, several specifics are important, such as the transducer's position parallel to the liver capsule, the ROI parallel to the transducer and perpendicular to the ARFI pulse, as well as the observer's focus on avoiding artefactual liver stiffening by taking the measurements $1.5-2 \mathrm{~cm}$ under the liver capsule. In order to obtain a value as accurate as possible, ten measurements are recommended in case of p-SWE and 5 for 2D-SWE [60]. Nevertheless, the quality criteria depends on the recommendation of each vendor [61]. The variability of measurements performed with p-SWE and 2D SWE was found to increase with liver stiffness [47]. It is worth mentioning that most of the data available in the literature focused on TE and several studies consider FibroScan as a reference for shear wave-based techniques [62,63]. Cut-off values for ultrasound-based elastography in children identified in the literature were summarized in Table 2.

\section{The Opportunities and Challenges of Ultrasound-Based Elastography in Children NAFLD}

Liver fibrosis in pediatric patients is commonly seen in the setting of fatty liver disease, hepatitis, primary sclerosing cholangitis, autoimmune hepatitis, congestive hepatopathy, cystic fibrosis, biliary atresia, Alagille syndrome, Fontan-associated liver disease, a-1 antitrypsin deficiency, storage disorders, and Wilson's disease [36,60]. Nevertheless, as we already mentioned, NAFLD has become one of the most common causes of chronic liver disease in pediatric populations due to the alarmingly persistent increasing incidence of obesity worldwide. Liver fibrosis is a common pathogenic feature of the above mentioned conditions and its assessment is extremely important in order to provide risk stratification, to guide therapeutic decision, and most important to monitor disease severity [26]. Taking into account the relatively low cost, the lack of invasive approach, no need for sedation, elastography might be a reliable alternative for the assessment of liver fibrosis. The importance of elastography methods for assessing liver fibrosis in adult patients is definitely incontestable, but in pediatric populations several challenges are related especially to their age-specific low compliance, resulting in possible invalid elastography measurement (Figures 3 and 4). Multiple confounding factors identified in pediatric populations were reported to influence liver stiffness on elastography, such as age, sedation, hepatic steatosis, or inflammation $[64,65]$. Hepatic congestion and inflammation, commonly seen in patients with congenital heart diseases and inflammatory liver disorders, might also result in increased liver stiffness unassociated with fibrosis [36,66]. 


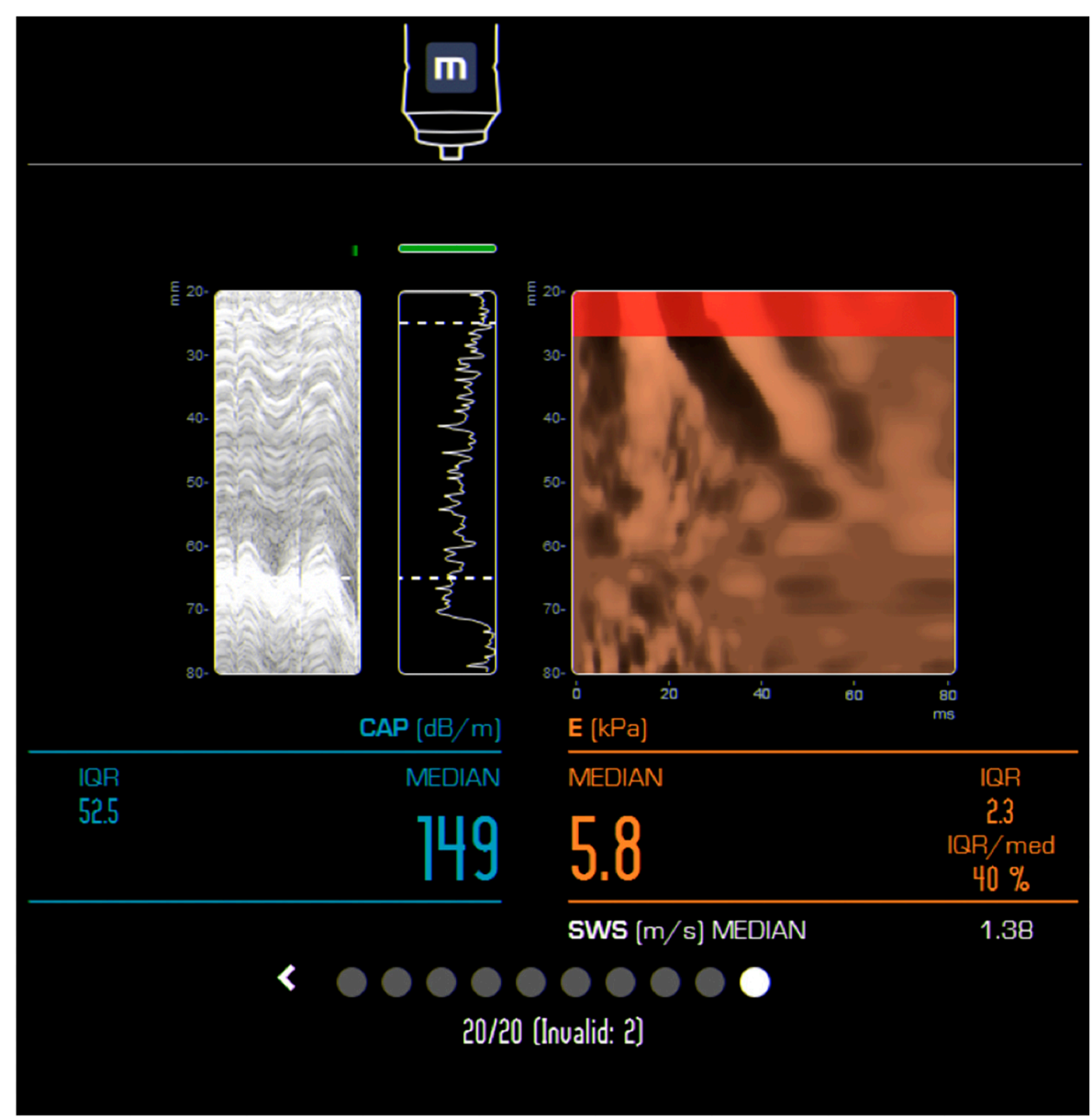

Figure 3. TE-liver invalid measurement (children).

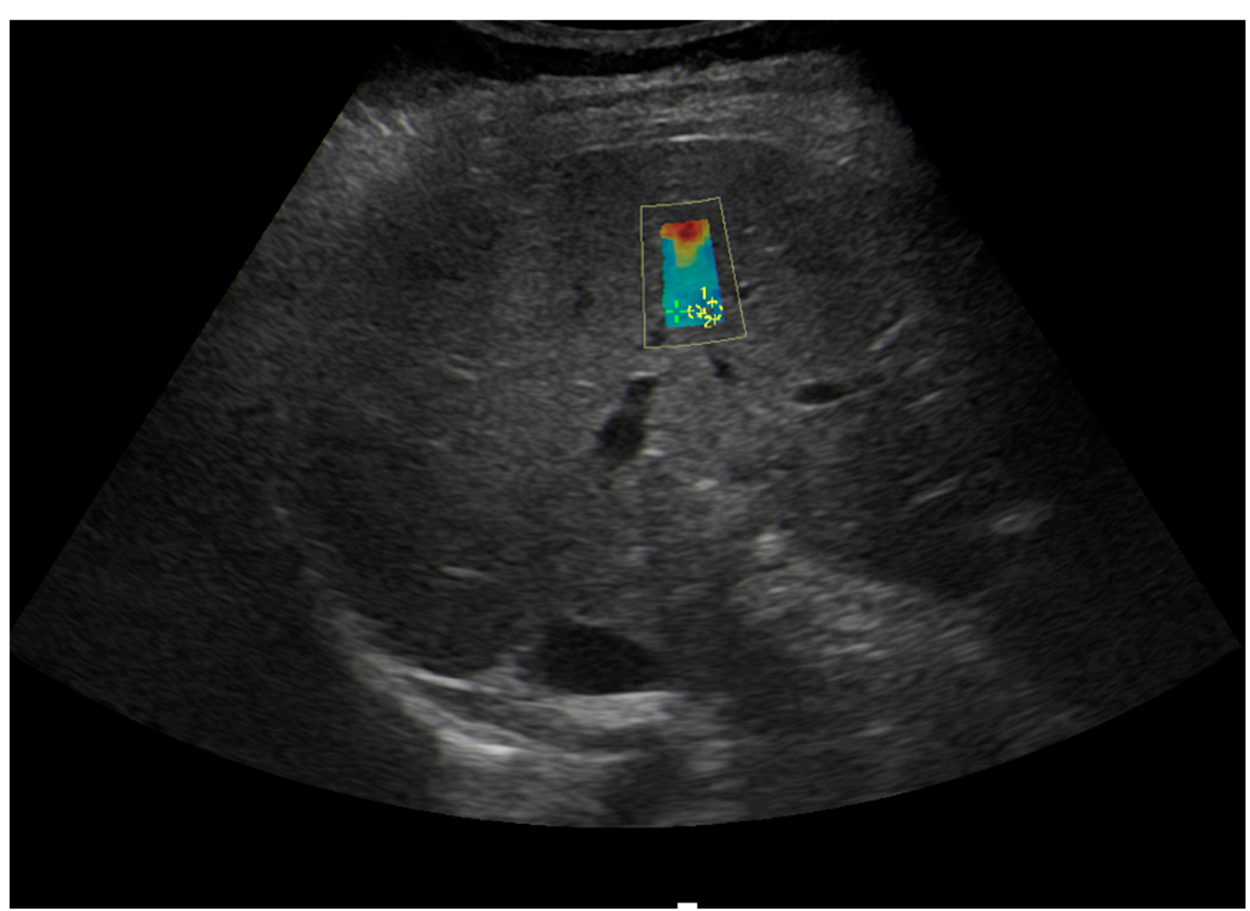

Figure 4. 2D-SWE-liver invalid measurement (children). 
Multiple studies revealed an increase in liver stiffness with age, but the results remain controversial since the association was found to be weak [64,67-70]. Thus, Li et al. proved a strong association between increasing age and liver stiffness measurements in children $\geq 3$ years [64]. It is most likely that these findings might be related to microstructure, vascular, and metabolic changes that occur during maturation as it was proved on animal models $[71,72]$. Similar trends were noticed by Tokuhara et al. in a study performed on 123 children using TE, who found a liver stiffness value of $3.4 \mathrm{kPa}$ between 1-5 years of age, $3.8 \mathrm{kPa}$ in children aged 6 to 11 years, and $4.1 \mathrm{kPa}$ in those aged 12 to 18 [73]. In addition, a study performed on 206 normal weight healthy children assessing liver stiffness using both 2D SWE and TE identified an increase in elastography values on both methods directly related to the individual's age. This study pointed out that the cutoff values on 2D SWE ranged between $4.13 \mathrm{kPa}$ in children aged between $3-5$ years and 4.88 in those between 12 to 15; while on TE these values varied from $4.40 \mathrm{kPa}$ between 3-5 years of age and $5.1 \mathrm{kPa}$ in adolescents aged 15-18 years [74]. It is also worth mentioning that according to Goldschmidt et al., liver stiffness values are not affected by either age or gender in children, who found a normal median liver stiffness value of $4.5 \mathrm{kPa}$ in healthy children with no comorbidities, without assessing other laboratory parameters, such as serum liver enzymes or APRI [75]. Therefore, age represents a potential limitation as well as a challenge in the assessment of liver stiffness on elastography and it should be taken into account as a potential confounder in order to increase the accuracy of these methods. 
Table 2. Stiffness values by different type of elastography in healthy children.

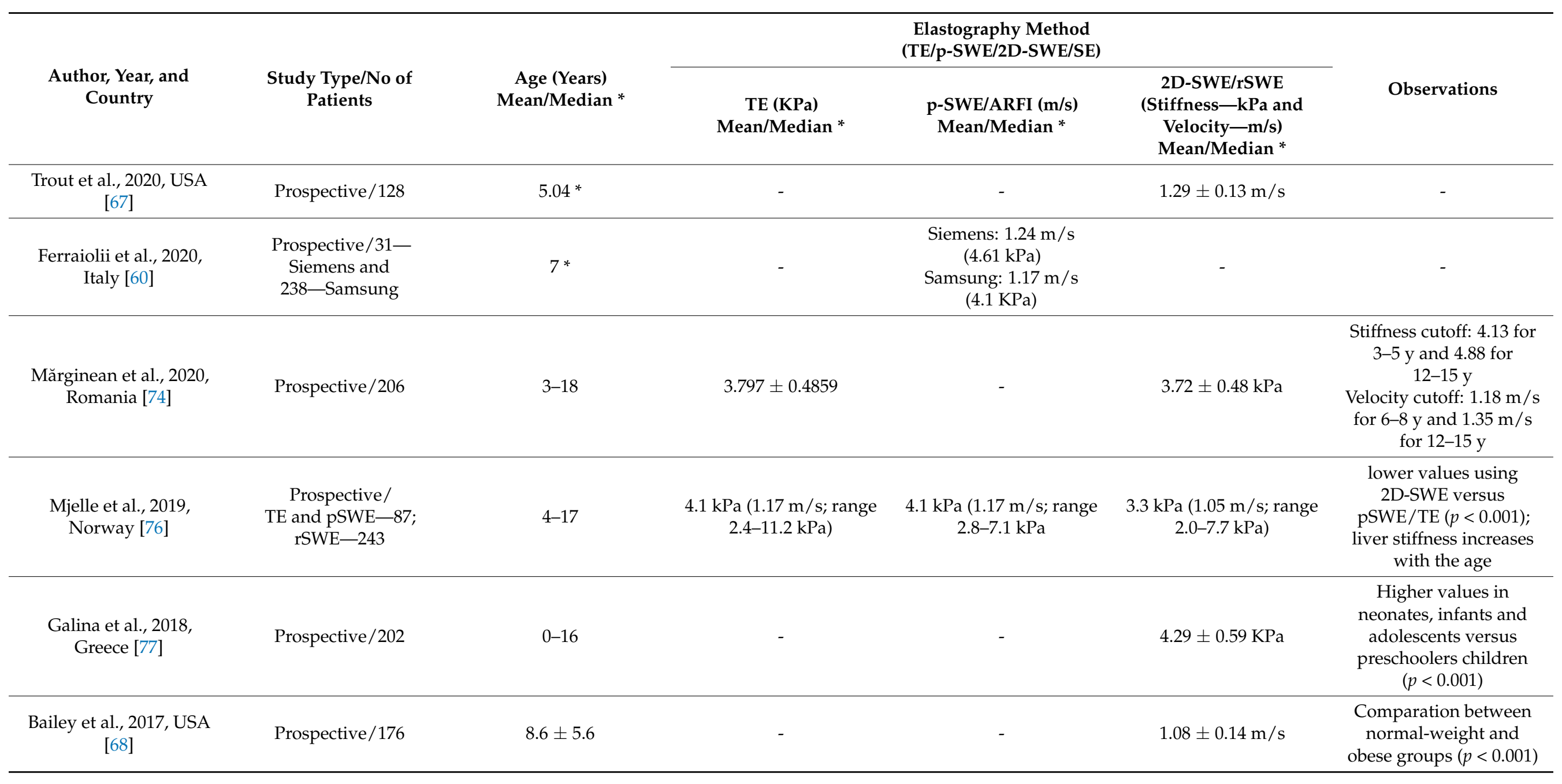


Table 2. Cont.

\begin{tabular}{|c|c|c|c|c|c|c|}
\hline \multirow[b]{2}{*}{$\begin{array}{l}\text { Author, Year, and } \\
\text { Country }\end{array}$} & \multirow[b]{2}{*}{$\begin{array}{c}\text { Study Type/No of } \\
\text { Patients }\end{array}$} & \multirow[b]{2}{*}{$\begin{array}{c}\text { Age (Years) } \\
\text { Mean/Median * }\end{array}$} & \multicolumn{3}{|c|}{$\begin{array}{c}\text { Elastography Method } \\
\text { (TE/p-SWE/2D-SWE/SE) }\end{array}$} & \multirow[b]{2}{*}{ Observations } \\
\hline & & & $\begin{array}{c}\text { TE (KPa) } \\
\text { Mean/Median * }\end{array}$ & $\begin{array}{l}\text { p-SWE/ARFI (m/s) } \\
\text { Mean/Median * }\end{array}$ & $\begin{array}{l}\text { 2D-SWE/rSWE } \\
\text { (Stiffness-kPa and } \\
\text { Velocity-m/s) } \\
\text { Mean/Median * }\end{array}$ & \\
\hline $\begin{array}{l}\text { Oskan et al., 2017, } \\
\text { Turkey [78] }\end{array}$ & Prospective/31 & $7^{*}$ & - & $1.24 \mathrm{~m} / \mathrm{s}$ & - & $\begin{array}{l}\text { pSWE in normal weight } \\
\text { compared cu obese } \\
\text { children }\end{array}$ \\
\hline $\begin{array}{l}\text { Franchi-Abella et al., } \\
\text { 2016, France [79] }\end{array}$ & Prospective/51 & $0-17.2$ & - & - & $6.58 \pm 1.46 \mathrm{KPa}$ & $\begin{array}{l}\text { elasticity value incresed } \\
\text { with age }\end{array}$ \\
\hline $\begin{array}{c}\text { Tokuhara et al., 2016, } \\
\text { Japan [73] }\end{array}$ & Prospective/123 & $11.7 *$ & $\begin{array}{c}3.4(2.3 \pm 4.6) \text { at } 1-5 \mathrm{y} \\
3.8(2.5 \pm 6.1) \text { at } 6-11 \mathrm{y} \\
4.1(3.3 \pm 7.9) \text { at } 12-18 \mathrm{y}\end{array}$ & - & - & $\begin{array}{l}\text { Median LSM increased } \\
\text { with age }(p<0.001)\end{array}$ \\
\hline $\begin{array}{l}\text { Lewindon et al., 2016, } \\
\text { Australia [80] }\end{array}$ & Prospective/64 & $9.3 \pm 0.5$ & $4.1 \pm 0.1$ & - & - & $\begin{array}{l}\text { Comparation between } \\
\text { normal weight and } \\
\text { intercurrent illness } \\
\text { groups }(p<0.001)\end{array}$ \\
\hline $\begin{array}{c}\text { Cho et al., 2015, Japan } \\
\text { [18] }\end{array}$ & Prospective/107 & $11.5^{*}$ & $3.9 \pm 0.9$ & - & - & $\begin{array}{c}\text { significant differences } \\
\text { between normal-weight } \\
\text { and obese } \\
\text { children }(p<0.001)\end{array}$ \\
\hline $\begin{array}{c}\text { Fontanilla et al., 2014, } \\
\text { Spain [69] }\end{array}$ & Prospective/60 & $\begin{array}{c}\text { Max } 14 \\
\text { (only range) }\end{array}$ & - & $\begin{array}{l}\text { 4C1 transducer: } 1.19^{*} \\
\text { 9L4 transducer: } 1.15^{*}\end{array}$ & & - \\
\hline $\begin{array}{l}\text { Matos et al., 2014, } \\
\text { Portugal [70] }\end{array}$ & Prospective/150 & $8.9^{* *}$ & - & $1.07^{*}$ & - & - \\
\hline $\begin{array}{l}\text { Tutar et al., 2014, Turkey } \\
\text { [81] }\end{array}$ & Prospective/50 & $7.4 *$ & - & - & $7.41 \mathrm{kPa} ; 1.56 \mathrm{~m} / \mathrm{s}$ & - \\
\hline
\end{tabular}


Table 2. Cont.

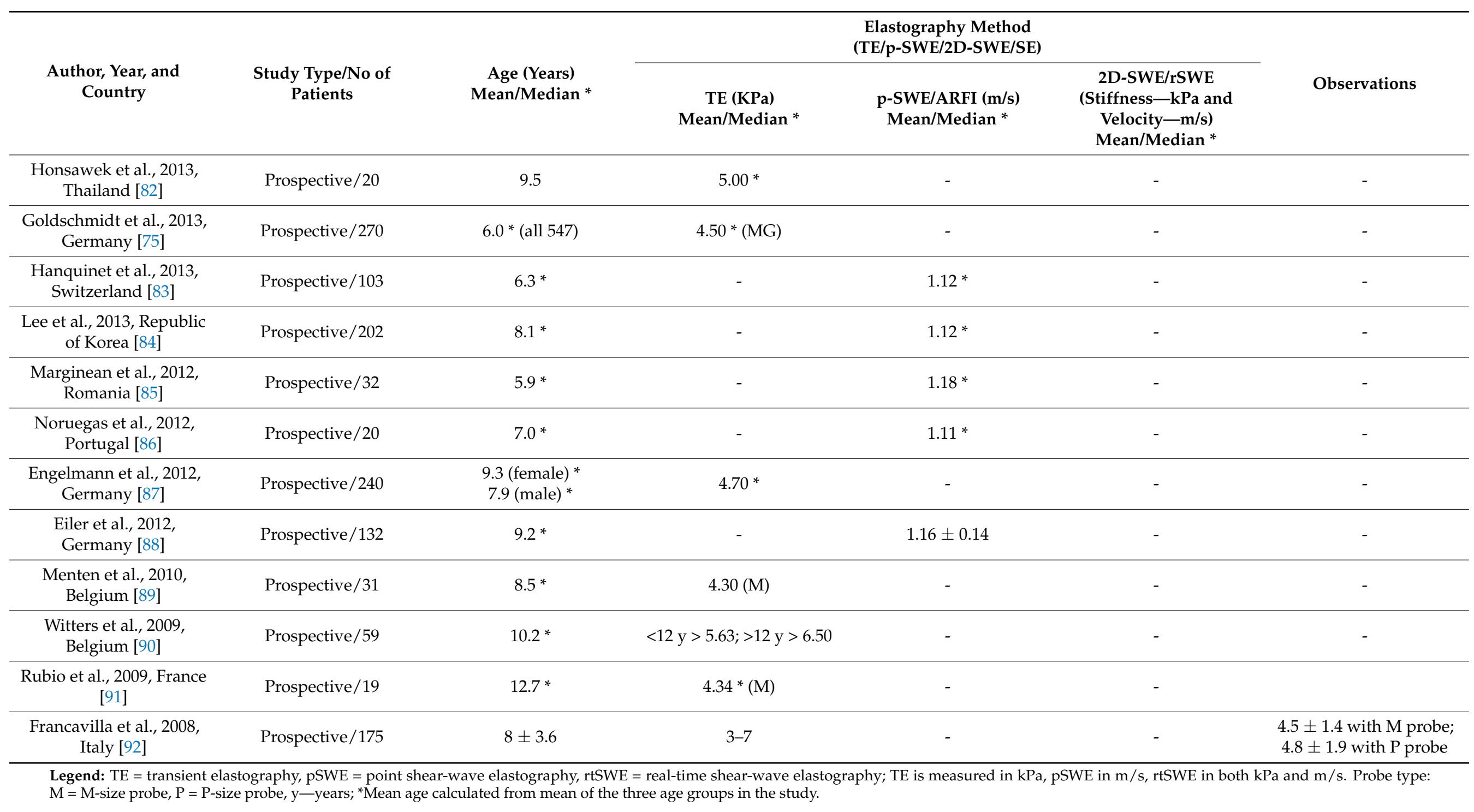


The most recent confounding factor identified in a study performed on patients with Hepatitis $\mathrm{C}$ virus (HCV) is represented by serum transaminases hypothesized to increase liver stiffness measurements. Thus, Giuffrè et al. proved as a result of a study on 110 patients with HCV that the probability of liver fibrosis overestimation of two or more grades equals $50 \%$ for AST of $99 \mathrm{IU} / \mathrm{L}$ and ALT of $90.5 \mathrm{IU} / \mathrm{L} ; 80 \%$ for AST of $123.5 \mathrm{IU} / \mathrm{L}$ and ALT of $101.5 \mathrm{IU} / \mathrm{L}$; and up to $100 \%$ for AST of $211 \mathrm{IU} / \mathrm{L}$ and ALT of $140 \mathrm{IU} / \mathrm{L}$ [93]. Nevertheless, no data is available to date in pediatric patients regarding the impact of serum transaminases on liver stiffness measurements. Blood flow is another potential confounding factor of liver stiffness since previous studies underlined that increased blood flow as a result of food intake leads to an increased liver stiffness [94]. Thus, a period of at least $4 \mathrm{~h}$ of fasting is recommended before the examination in order to avoid this confounding factor [95]. It is well-documented that elastography is of major importance in assessing portal hypertension, but it was proved that severe portal hypertension impairs the correlations between liver stiffness and hepatic venous pressure gradient, emphasizing that the assessment of spleen stiffness could be more reliable in these cases [96]. In terms of spleen stiffness assessment, a recent study performed on HCV patients proved that spleen stiffness increased by $3.220 \mathrm{kPa}$ for each $\mathrm{mm}$ of portal vein diameters and by $0.7 \mathrm{kPa}$ for each $\mathrm{cm} / \mathrm{s}$ of portal vein velocity, underlining that it might be an accurate parameter for portal hypertension stratification [97].

Taking into account the wide-spectrum of confounding factors identified in children with obesity, among which are obesity itself, fatty liver infiltration, a possible mild heart failure, and the incapacity to hold their breath, it is unsurprising that the reliability of elastography methods is closely related to body mass index [98], requiring the combination of these methods with other clinical and laboratory findings. In compliance to the abovementioned facts, the study of Nobili et al. noticed that a body mass index greater than 35 in children might result in failure to obtain valid TE measurements [99]. This limitation is defined by the impact of skin-to-liver distance on the feasibility and accuracy of liver elastography. In terms of elastography, it was hypothesized that skin-to-liver distance $<34 \mathrm{~mm}$ is optimal for discriminating between fibrosis stages [100]. This hypothesis is in line with other studies which concluded that in patients with a BMI $\geq 30 \mathrm{~kg} / \mathrm{m}^{2}$, elastography has a relatively low accuracy in differentiating between the first two fibrosis stages [101,102]. It was also underlined that the success rate in obese patients depends on the technique being proved that TE has a higher failure rate in this group when compared to p-SWE [101]. Moreover, a recent study performed on obese adults emphasized that p-SWE is able to discriminate between fibrosis stages independently of its severity if skin-to-liver distance is taken into account following two rules: a thicker abdominal wall results in a lesser accuracy for a proper histological staging and the impact of skin-to-liver distance on accurate fibrosis staging is machine-dependent [103]. In terms of ARFI, it was showed that interoperator concordance increases when skin-to-liver distance is $<2.5 \mathrm{~cm}$ [104], being previously documented that a higher concordance is reflected on the correlation between fibrosis stages assessed on ARFI and histology [105]. Using TE, another recent study proved that a skin capsular distance $\geq 25 \mathrm{~mm}$ results in overestimation of fibrosis affecting the detection of severe fibrosis in patients with NAFLD [106]. Thus, this is an important challenge that should be addressed also in children with NAFLD since to date we found no study on this topic in pediatric patients with NAFLD.

The accuracy of elastography methods might be improved if combined with other clinical or laboratory parameters in order to face the aforementioned challenges/limitations. A recent review which included 27 articles underlined that elastography is a reliable method in diagnosing liver fibrosis and cirrhosis in pediatric patients, whose accuracy is improved when used in combination with other clinical tools, such as serum markers [107]. Previous studies revealed positive associations between ultrasound-based elastography methods and several laboratory parameters such as ALT, APRI, or AST/ALT ratio (AAR), which are well-known to be increased in children with obesity $[18,19,108]$. The study of Kamble et al. used ARFI in combination with serum liver enzymes and triglyceride values and 
proved that liver stiffness is significantly correlated with liver enzymes and most children identified with a value above $1.19 \mathrm{~m} / \mathrm{s}$ associated AAR $>0.8$, defined also as a potential indicator of steatohepatitis [109]. Therefore, the combination between these laboratory parameters and elastography values might increase the accuracy in detecting and staging liver fibrosis in children with obesity.

Multiple studies aimed to compare the performance of ultrasound-based elastography methods in NAFLD patients. Kim et al. stated after reviewing 12 articles that fibrosis in children can be predicted with a higher sensitivity and specificity using supersonic shear imaging in comparison with ARFI, with an increasing accuracy in the setting of advanced fibrosis. The authors pointed out that the reference values according to ARFI are $1.34 \mathrm{~m} / \mathrm{s}$ in case of stage 1 fibrosis, $1.57 \mathrm{~m} / \mathrm{s}$ in stage $2,1.85 \mathrm{~m} / \mathrm{s}$ for stage 3 , and $2.13 \mathrm{~m} / \mathrm{s}$ for stage 4. Contrarily, in terms of supersonic shear imaging, the authors found a median cutoff value of $7.9 \mathrm{kPa}$ in case of stage 1, $9.4 \mathrm{kPa}$ in stage 2, $14.2 \mathrm{kPa}$ for stage 3, and $23.94 \mathrm{kPa}$ for stage 4 [110], although for ARFI the results are provided in $\mathrm{m} / \mathrm{s}$. For supersonic shear imaging such as Young's modulus in $\mathrm{kPa}$, both elastography methods reveal increasing values as liver fibrosis advances. Similar trends were provided by Mărginean et al., who reported the results of 2D-SWE as both $\mathrm{m} / \mathrm{s}$ and Young's modulus in $\mathrm{kPa}$ [19]. Based on these findings we might assume that the values liver stiffness assessed in $\mathrm{m} / \mathrm{s}$ or in $\mathrm{kPa}$ are directly related since an increase in both in noticed in stiffer livers. Another study which assessed the differences between ARFI and TE on children with chronic liver disease in the setting of metabolic disorders, as well as those with normal liver, suggested that ARFI might be more accurate differentiating between the stages of fibrosis [111]. Similar findings were reported by Garcovich et al., concluding that 2D-SWE might be considered reliable in detecting advanced liver fibrosis in children with NASH [112]. Contrarily, Mărginean et al., who assessed liver stiffness in children with obesity using both TE and 2D-SWE, pointed out that TE and velocity measured on 2D-SWE might represent useful tools for detecting NAFLD [19]. Overall, Lee et al. concluded in a comparative study which assessed the diagnostic performance of supersonic shear imaging, TE and ARFI in NAFLD staging that all these methods have similar diagnostic performance for staging fibrosis in the setting of NAFLD [113].

A major limitation of elastography methods is represented by a proper differentiation between mild fibrosis and normal liver tissue. Thus, pSWE was found to have a good accuracy in distinguishing severe from mild fibrosis, but not between normal liver tissue and low-grade fibrosis in children with NAFLD [78]. The increased risk of mortality in patients with NAFLD is mostly related to liver fibrosis itself [114] and its proper diagnosis, as well as its early staging are crucial for improving the long-term prognosis in children with overweight and obesity. A very recent study that compared liver stiffness values on 2D SWE and TE proved higher values in children with obesity as compared to normal ones, suggesting that these methods might be extremely useful in clinical practice for detecting early stages of fibrosis associated to NAFLD [19]. Furthermore, in order to increase the reliability of TE, Alkhouri et al. combined this technique with pediatric NAFLD index and showed that this combination might identify patients that require liver biopsy for advanced fibrosis confirmation and closer follow-up for a timely diagnosis of cirrhosisrelated complications [115]. The most relevant studies that compared the results between liver elastography and biopsy findings in children NAFLD were summarized in Table 3.

In terms of pediatric NAFLD staging, studies that assessed the role of elastography are promising although its precision is not perhaps optimal. Multiple studies aimed to identify if elastography is able to replace liver biopsy in order to diagnose this condition, an emerging concern worldwide. Two histology scoring systems were used for assessing liver fibrosis: Brunt classification [116] defined as grade 0 for no fibrosis, grade 1 for zone 3 perisinusoidal and/or pericellular fibrosis, grade 2-the changes identified in grade 1 plus focal or extensive periportal fibrosis, grade 3 as in grade 2 plus focal or extensive bridging fibrosis and grade 4 defining cirrhosis; and Kleiner activity scoring system with 0 for no fibrosis, 1 for periportal or perisinusoidal fibrosis, 2 for perisinusoidal and portal or 
periportal fibrosis, 3 for bridging fibrosis, and 4 when cirrhosis occurs [117]. Garcovich et al. performed a study on 68 pediatric patients with histologically proven NASH according to the Brunt scoring system, and found that SWE established correctly the fibrosis stage in 57 of 68 patients $(84 \%)$, with higher accuracy in patients with advanced fibrosis. The authors encountered that $6.7 \mathrm{kPa}$ might be a reliable cutoff value for delineating fibrosis stages [112]. Similar findings were reported by Alkhouri et al. on 67 children with histologically proven NAFLD according to the Kleiner's system, who stated that TE is a useful non-invasive indicator of clinically significant liver fibrosis guiding the proper selection of patients that require liver biopsy [115]. Another recent meta-analysis involving 723 patients underlined that TE represents is a highly accurate method for the diagnosis of liver fibrosis in children with a sensitivity of $95 \%$ and a specificity of $90 \%$ in the setting of significant liver fibrosis, above stage 2 [118]. The most relevant studies that assessed NAFLD in children using ultrasound-elastography based methods are described in Table 4 .

Conventional ultrasound might also reveal certain liver abnormalities indicative of liver steatosis or fibrosis, such as abnormal echogenicity or focal lesions, but its capacity is definitely overpassed by elastography. Therefore, a study that compared SWE and conventional ultrasound findings in children with obesity and normal weight ones pointed out that mean SWE velocity values were significantly higher in the obese group with abnormal liver echogenicity at conventional ultrasound that in those with apparently normal aspect of liver, but the authors failed in identifying a significant difference in normal weight children [68]. In terms of conventional ultrasound, similar findings were identified by Mărginean et al., who showed that children with overweight/obesity are more frequently identified with abnormal liver aspects, such as hepatomegaly and hyperchogenicity as compared to normal weight ones [5]. Thus, conventional ultrasound might represent the first step in assessing children with obesity and diagnosing NAFLD [119] in order to guide them for elastography staging, which is definitely associated with greater costs. Contrarily, a study performed on 148 school-aged children concluded as a result of ARFI examination that significant liver fibrosis might be present even in the setting of normal laboratory parameters or normal ultrasound liver aspect [120].

Table 3. Elastography in children with nonalcoholic fatty liver disease (NAFLD)/non-alcoholic steatohepatitis (NASH) compared to histological findings obtained by liver biopsy (gold standard).

\begin{tabular}{|c|c|c|c|c|c|c|c|}
\hline $\begin{array}{l}\text { Author, Year, } \\
\text { and Country }\end{array}$ & $\begin{array}{c}\text { Study Type } \\
\text { and No } \\
\text { Patients }\end{array}$ & $\begin{array}{c}\text { Age (Years) } \\
\text { Mean/Median * }\end{array}$ & Diagnosis & $\begin{array}{c}\text { Gold } \\
\text { Standard } \\
\text { and Score } \\
\text { Type }\end{array}$ & $\begin{array}{c}\text { Elastography } \\
\text { Method } \\
\text { (TE/p- } \\
\text { SWE/2D- } \\
\text { SWE } \\
\text { (pSWE) }\end{array}$ & $\begin{array}{l}\text { Elastography } \\
\text { Values } \\
\text { Mean/Median }\end{array}$ & $\begin{array}{c}\text { Correlation } \\
\text { to Gold } \\
\text { Standard/Cut- } \\
\text { off } \\
\text { AUROC }\end{array}$ \\
\hline $\begin{array}{c}\text { Hudert et al., } \\
\text { 2018, } \\
\text { Germany } \\
{[121]}\end{array}$ & Prospective/47 & $14.1 \pm 2.2$ & NAFLD/NASH & $\begin{array}{l}\text { Biopsy, } \\
\text { Kleiner }\end{array}$ & $\begin{array}{l}\text { Harmonic } \\
\text { SWE }\end{array}$ & $\begin{array}{c}\text { F0: } 1.45 \pm \\
0.05 \mathrm{~m} / \mathrm{s} \\
\text { F1: } 1.49 \pm \\
0.07 \mathrm{~m} / \mathrm{s} \\
\text { F2: } 1.78 \pm \\
0.13 \mathrm{~m} / \mathrm{s} \\
\text { F3: } 1.81 \pm \\
0.11 \mathrm{~m} / \mathrm{s}\end{array}$ & $\begin{array}{l}\text { Usefull for } \\
\text { detection of } \\
\text { moderate } \\
\text { fibrosis in } \\
\text { extreme } \\
\text { obese } \\
\text { children } \\
\text { Cutoffs: F1: } \\
1.52 \mathrm{~m} / \mathrm{s} ; \mathrm{F} 2: \\
1.62 \mathrm{~m} / \mathrm{s} ; \mathrm{F} 3: \\
1.64 \mathrm{~m} / \mathrm{s}\end{array}$ \\
\hline
\end{tabular}


Table 3. Cont

\begin{tabular}{|c|c|c|c|c|c|c|c|}
\hline $\begin{array}{l}\text { Author, Year, } \\
\text { and Country }\end{array}$ & $\begin{array}{c}\text { Study Type } \\
\text { and No } \\
\text { Patients }\end{array}$ & $\begin{array}{c}\text { Age (Years) } \\
\text { Mean/Median } \\
*\end{array}$ & Diagnosis & $\begin{array}{c}\text { Gold } \\
\text { Standard } \\
\text { and Score } \\
\text { Type }\end{array}$ & $\begin{array}{c}\text { Elastography } \\
\text { Method } \\
\text { (TE/p- } \\
\text { SWE/2D- } \\
\text { SWE } \\
\text { (pSWE) }\end{array}$ & $\begin{array}{l}\text { Elastography } \\
\text { Values } \\
\text { Mean/Median }\end{array}$ & $\begin{array}{c}\text { Correlation } \\
\text { to Gold } \\
\text { Standard/Cut- } \\
\text { off } \\
\text { AUROC }\end{array}$ \\
\hline $\begin{array}{c}\text { Oskan et al., } \\
\text { 2017, Turkey } \\
\text { [78] }\end{array}$ & Prospective/11 & $9 *$ & NAFLD & $\begin{array}{l}\text { Biopsy, } \\
\text { Knodell }\end{array}$ & pSWE & $\begin{array}{c}1.56 \mathrm{~m} / \mathrm{s} \\
\text { (range, } \\
1.32-2.03 \\
\mathrm{~m} / \mathrm{s} \text { ) }\end{array}$ & $\begin{array}{c}\text { pSWE- } \\
\text { increased in } \\
\text { fibrosis; } \\
\text { Cutoff: } 2.09 \\
\text { m/s VTQ; } \\
\text { pSWE cutoff: } \\
1.67 \mathrm{~m} / \mathrm{s}\end{array}$ \\
\hline $\begin{array}{c}\text { Cho et al., } \\
\text { 2015, Japan } \\
\text { [18] }\end{array}$ & Prospective/52 & $11.5^{*}$ & NAFLD & $\begin{array}{c}\text { Biopsy only } \\
\text { in } 8 \\
\text { children, } \\
\text { Kleiner }\end{array}$ & TE & $5.5 \pm 2.3 \mathrm{kPa}$ & $\begin{array}{c}\text { highly } \\
\text { correlated } \\
\text { with fibrosis } \\
\text { stage } \\
\text { (Spearman's } \\
\rho=0.920)\end{array}$ \\
\hline $\begin{array}{l}\text { Garcovich } \\
\text { et al., 2016, } \\
\text { Italy [112] }\end{array}$ & Prospective/68 & $12.6 \pm 2.48$ & $\mathrm{NASH}$ & $\begin{array}{c}\text { Biopsy, } \\
\text { Brunt }\end{array}$ & rSWE & $\begin{array}{c}\text { F0: } 4.4 \pm 0.6 \\
\mathrm{KPa} \\
\text { F1: } 5.6 \pm 0.6 \\
\mathrm{KPa} \\
\text { F2: } 7.1 \pm 0.7 \\
\mathrm{KPa}\end{array}$ & $\begin{array}{c}\text { Significant } \\
\text { correlation } \\
\text { with liver } \\
\text { fibrosis } \\
(\mathrm{r}=0.84 \\
p<0.001)\end{array}$ \\
\hline $\begin{array}{l}\text { Alkhouri } \\
\text { et al., 2013, } \\
\text { USA [115] }\end{array}$ & Prospective/67 & $\begin{array}{c}\text { Min 5.5; } \\
\text { Max } 11.3 \\
\text { (only range) }\end{array}$ & NAFLD & $\begin{array}{l}\text { Biopsy, } \\
\text { Kleiner }\end{array}$ & TE (S) & $\begin{array}{c}\text { F0-F1: } 5.7 \pm \\
1.2 \mathrm{kPa} \\
\text { F2-F3: } 10.9 \pm \\
3.3 \mathrm{kPa}\end{array}$ & $\begin{array}{c}\text { Significant } \\
\text { difference } \\
\text { between TE } \\
\text { at F0-1 and } \\
\text { F2-3 } \\
(p<0.001) \\
\geq \text { F2: } 8.6 \\
(1.00)\end{array}$ \\
\hline $\begin{array}{c}\text { Marginean } \\
\text { et al., 2012, } \\
\text { Romania [85] }\end{array}$ & Prospective/13 & $7.9 *$ & NAFLD & Biopsy, (-) & pSWE & $\begin{array}{c}1.65 \pm 0.49 \\
\mathrm{~m} / \mathrm{s}\end{array}$ & $\begin{array}{l}\text { significant } \\
\text { difference } \\
\text { between } \\
\text { NAFLD and } \\
\text { healthy } \\
\text { controls } \\
(p<0.05)\end{array}$ \\
\hline $\begin{array}{c}\text { Nobili et al., } \\
\text { 2008, Italy } \\
\text { [99] }\end{array}$ & Prospective/50 & $13.6^{*}$ & NASH & $\begin{array}{l}\text { Biopsy, } \\
\text { Brunt }\end{array}$ & TE (M) & $\begin{array}{c}\text { F0: } 4.4 \mathrm{kPa} ; \\
\text { F1: } 6.1 \mathrm{kPa} ; \\
\text { F2: } 8.6 \mathrm{kPa} ; \\
\text { F3-4: } 20.4 \\
\text { kPa }\end{array}$ & $\begin{array}{c}\text { Cut-off: } \geq \mathrm{F} 1: \\
5.1(0.97) \\
\geq \mathrm{F} 2: 7.4 \\
(0.99) ; \geq \mathrm{F} 3: \\
10.2(1.00)\end{array}$ \\
\hline
\end{tabular}

Legend: TE = transient elastography, $\mathrm{pSWE}=$ point shear-wave elastography, rtSWE = real-time shear-wave elastography. TE is measured in $\mathrm{kPa}$, pSWE in $\mathrm{m} / \mathrm{s}$, rtSWE in both $\mathrm{kPa}$ and $\mathrm{m} / \mathrm{s}$; NAFLD = non-alcoholic fatty liver disease, NASH = non-alcoholic steato-hepatitis, VTQ

$=$ Virtual Touch quantification; *Mean age calculated. 
Table 4. Elastography in healthy versus NAFLD/NASH children.

\begin{tabular}{|c|c|c|c|c|c|c|}
\hline $\begin{array}{l}\text { Author, Year, } \\
\text { and Country }\end{array}$ & $\begin{array}{l}\text { Study Type } \\
\text { and No } \\
\text { Patients } \\
\text { (Normal } \\
\text { Weight/Obese } \\
\text { Children) }\end{array}$ & $\begin{array}{c}\text { Age (Years) } \\
\text { Mean/Median } \\
*\end{array}$ & $\begin{array}{l}\text { Elastography } \\
\text { Method (TE/p- } \\
\text { SWE/2D-SWE } \\
\text { (rSWE) }\end{array}$ & $\begin{array}{l}\text { Elastogpraphy } \\
\text { in Healty } \\
\text { Children } \\
\text { (Mean/Median) }\end{array}$ & $\begin{array}{l}\text { Elastography } \\
\text { Values in } \\
\text { NAFLD/NASH } \\
\text { (Mean/Median) }\end{array}$ & $\begin{array}{l}\text { Correlations/ } \\
\text { Observations }\end{array}$ \\
\hline $\begin{array}{c}\text { Mjelle et al., } \\
\text { 2019, Norway } \\
\text { [76] }\end{array}$ & $\begin{array}{c}\text { Prospective } \\
243 / 27\end{array}$ & $4-17$ & $\begin{array}{l}\text { 2D-SWE } \\
\text { pSWE } \\
\text { TE }\end{array}$ & $\begin{array}{c}8-11 \mathrm{y}: 3.35 \mathrm{kPa} \\
15-17 \mathrm{y}: 3.78 \\
\mathrm{kPa} \\
4.1 \mathrm{kPa} \\
15-17 \mathrm{y}: 4.52 \\
\mathrm{kPa}\end{array}$ & $\begin{array}{c}8-11 \mathrm{y}: 4.45 \mathrm{kPa} \\
15-17 \mathrm{y}: 4.64 \\
\mathrm{kPa} \\
8-11 \mathrm{y}: 4.1 \mathrm{kPa} \\
15-17 \mathrm{y}: 3.4 \mathrm{kPa}\end{array}$ & $\begin{array}{c}\text { Significant } \\
\text { corellation } \\
(p<0.001 / \\
p<0.008) \\
\text { Significant } \\
\text { corellation, } \\
p=0.003 \\
\text { TE lower LSM } \\
\text { values in the } \\
\text { overweight }\end{array}$ \\
\hline $\begin{array}{c}\text { Mărginean } \\
\text { et al., 2019, } \\
\text { Romania [19] }\end{array}$ & $\begin{array}{c}\text { Prospective } \\
210 / 77\end{array}$ & $\begin{array}{c}11.29 \pm 3.83 \\
y-\text { normal } \\
\text { weigh } \\
10.44 \pm 3.38 \\
y-\text { obese }\end{array}$ & $\begin{array}{c}\mathrm{TE} \\
\text { 2D-SWE }\end{array}$ & $\begin{array}{l}3.80 \pm 0.48 \mathrm{kPa} \\
3.73 \pm 0.48 \mathrm{kPa} \\
1.09 \pm 0.09 \mathrm{~m} / \mathrm{s}\end{array}$ & $\begin{array}{l}4.23 \pm 0.53 \mathrm{kPa} \\
3.84 \pm 0.35 \mathrm{kPa} \\
1.18 \pm 0.09 \mathrm{~m} / \mathrm{s}\end{array}$ & $\begin{array}{c}p<0.0001 \\
p=0.0314 / p< \\
0.0001 \\
\text { AUC: V median: } \\
0.817 \pm 0.028 \\
(p=0.0001) ; \mathrm{TE}: \\
0.730 \pm 0.033(p \\
=0.0001)\end{array}$ \\
\hline $\begin{array}{l}\text { Bailey et al., } \\
\text { 2017, USA [68] }\end{array}$ & $\begin{array}{c}\text { Prospective } \\
176 / 124\end{array}$ & $9.9 \pm 5.3$ & 2D-SWE & $1.08 \pm 0.14 \mathrm{~m} / \mathrm{s}$ & $1.44 \pm 0.39 \mathrm{~m} / \mathrm{s}$ & $\begin{array}{c}\text { significant } \\
\text { differences } \\
\text { between } \\
\text { normal-weight } \\
\text { and obese } \\
\text { children } \\
(p<0.001) ; \\
\text { Kappa } \\
\text { coefficient = } \\
0.64\end{array}$ \\
\hline $\begin{array}{c}\text { Berna'-Serna } \\
\text { et al., 2017, } \\
\text { Spain [120] }\end{array}$ & $\begin{array}{l}\text { Prospective } \\
-/ 148\end{array}$ & $8.02 \pm 1.64$ & pSWE (ARFI) & - & $\begin{array}{l}\text { F0: } 1.03 \pm 0.13 \\
\text { F1:1.24 } \\
\text { F2: } 1.40 \pm 0.04 \\
\text { F3: } 1.75 \pm 0.08 \\
\text { F4: } 2.21 \pm 0.28\end{array}$ & $\begin{array}{l}\text { Significant } \\
\text { difference } \\
\text { between boys } \\
\text { and girls } \\
(p=0.0003)\end{array}$ \\
\hline $\begin{array}{c}\text { Oskan et al., } \\
\text { 2017, Turkey } \\
\text { [78] }\end{array}$ & $\begin{array}{c}\text { Prospective } \\
31 / 11\end{array}$ & $\begin{array}{l}7 * \\
9 *\end{array}$ & pSWE & $1.24 \mathrm{~m} / \mathrm{s}$ & $\begin{array}{l}1.56 \mathrm{~m} / \mathrm{s}(\text { range, } \\
1.32-2.03 \mathrm{~m} / \mathrm{s})\end{array}$ & $\begin{array}{c}\text { pSWE } \\
\text { significant } \\
\text { higher in obese } \\
\text { versus normal } \\
\text { weight } \\
(p<0.001)\end{array}$ \\
\hline $\begin{array}{c}\text { Cho et al., 2015, } \\
\text { Japan [18] }\end{array}$ & $\begin{array}{c}\text { Prospective } \\
107 / 52\end{array}$ & $11.5^{*}$ & $\mathrm{TE}$ & $3.9 \pm 0.9 \mathrm{kPa}$ & $5.5 \pm 2.3 \mathrm{kPa}$ & $\begin{array}{l}\text { significant } \\
\text { differences } \\
\text { between } \\
\text { normal-weight } \\
\text { and obese } \\
\text { children } \\
(p<0.001)\end{array}$ \\
\hline
\end{tabular}


Table 4. Cont.

\begin{tabular}{|c|c|c|c|c|c|c|}
\hline $\begin{array}{l}\text { Author, Year, } \\
\text { and Country }\end{array}$ & $\begin{array}{l}\text { Study Type } \\
\text { and No } \\
\text { Patients } \\
\text { (Normal } \\
\text { Weight/Obese } \\
\text { Children) }\end{array}$ & $\begin{array}{c}\text { Age (Years) } \\
\text { Mean/Median } \\
*\end{array}$ & $\begin{array}{l}\text { Elastography } \\
\text { Method (TE/p- } \\
\text { SWE/2D-SWE } \\
\text { (rSWE) }\end{array}$ & $\begin{array}{l}\text { Elastogpraphy } \\
\text { in Healty } \\
\text { Children } \\
\text { (Mean/Median) }\end{array}$ & $\begin{array}{l}\text { Elastography } \\
\text { Values in } \\
\text { NAFLD/NASH } \\
\text { (Mean/Median) }\end{array}$ & $\begin{array}{l}\text { Correlations/ } \\
\text { Observations }\end{array}$ \\
\hline $\begin{array}{c}\text { Fitzpatrick } \\
\text { et al., 2013, Italy } \\
{[122]}\end{array}$ & $\begin{array}{c}\text { Prospective/ } \\
-/ 37\end{array}$ & $13.5^{*}$ & $\mathrm{TE}$ & - & $\begin{array}{l}\text { F0: } 6.1 \mathrm{kPa} ; \mathrm{F} 1: \\
\text { 5.1 kPa; F2: } 5.8 \\
\mathrm{kPa} \text {; F3: } 7.4 \mathrm{kPa}\end{array}$ & $\begin{array}{c}\text { For severe } \\
\text { fibrosis, the } \\
\text { AUROC was } \\
0.8(p=0.003) ; \mathrm{a} \\
\text { cutoff of } 6.9 \mathrm{kPa} \\
\text { had a } 72 \% \\
\text { sensitivity and } \\
\text { a } 85 \% \\
\text { specificity }\end{array}$ \\
\hline
\end{tabular}

Legend: TE = transient elastography, pSWE = point shear-wave elastography, rtSWE = real-time shear-wave elastography; TE is measured in $\mathrm{kPa}$, pSWE in $\mathrm{m} / \mathrm{s}, \mathrm{rtSWE}$ in both $\mathrm{kPa}$ and $\mathrm{m} / \mathrm{s}$. ARFI = acoustic radiation force impulse measured in $\mathrm{m} / \mathrm{s}, \mathrm{NAFLD}=$ non alcoholic fatty liver disease, $\mathrm{NASH}=$ non-alcoholic steatohepatitis, AUC—area under curve, $\mathrm{y}$-years; $\mathrm{V}$ = velocity; ${ }^{*}$ Mean age calculated.

\section{Conclusions}

NAFLD is most likely a real challenge for pediatricians and its proper diagnosis and close follow-up are essential for preventing further life-threatening complications, such as cirrhosis, end-stage liver disease, or hepatocarcinoma. Taking into account the expressed need for non-invasive approach in pediatric patients as compared to adults, elastography methods represent promising diagnostic tools with a relatively good accuracy for NAFLD staging. Nevertheless, multiple confounding factors should be closely monitored when assessing NAFLD children on elastography, such as age, BMI, transaminase levels, or portal blood flow. A complex approach combining elastography parameters with clinical and laboratory findings might increase the accuracy of ultrasound-based elastography in terms of NAFLD staging. Albeit elastography is limited in differentiating between mild fibrosis and normal liver, it is extremely useful for diagnosing liver fibrosis in children with obesity. Moreover, elastography is crucial for NAFLD monitoring and for guiding liver biopsy in selected cases. Still, multiple controversies arose due to their relatively novel use for young ages, and further studies are required in order to define their role in delineating the stages of liver fibrosis in children with obesity.

Author Contributions: L.E.M., C.O.M. and M.O.S. conceptualized and designed the study, drafted the initial manuscript, and reviewed and revised the manuscript. All authors have read and agreed to the published version of the manuscript.

Funding: This review received no external funding.

Institutional Review Board Statement: Not applicable.

Informed Consent Statement: Not applicable.

Conflicts of Interest: The authors declare no conflict of interest.

\section{References}

1. WHO | Overweight and Obesity. Available online: http://www.who.int/gho/ncd/risk_factors/overweight_adolescents_text/ en/ (accessed on 27 March 2021).

2. Mărginean, C.O.; Mărginean, C.; Meliţ, L.E. New Insights Regarding Genetic Aspects of Childhood Obesity: A Minireview. Front Pediatr. 2018, 6, 271. [CrossRef]

3. Mărginean, C.O.; Meliț, L.E.; Huțanu, A.; Ghiga, D.V.; Săsăran, M.O. The Gap between Overweight and Obesity Status in Children - (STROBE-Compliant Article). Medicine (Baltimore) 2021, 100, e24520. [CrossRef]

4. Pecht, T.; Gutman-Tirosh, A.; Bashan, N.; Rudich, A. Peripheral Blood Leucocyte Subclasses as Potential Biomarkers of Adipose Tissue Inflammation and Obesity Subphenotypes in Humans. Obes. Rev. 2014, 15, 322-337. [CrossRef] 
5. Mărginean, C.; Melit, L.; Ghiga, D.; Mărginean, M. Early Inflammatory Status Related to Pediatric Obesity (STROBE Compliant Article). Front Pediatr. 2019, 7. [CrossRef]

6. Mărginean, C.O.; Meliţ, L.E.; Huțanu, A.; Ghiga, D.V.; Săsăran, M.O. The Adipokines and Inflammatory Status in the Era of Pediatric Obesity. Cytokine 2020, 126, 154925. [CrossRef] [PubMed]

7. Schwimmer, J.B.; Deutsch, R.; Kahen, T.; Lavine, J.E.; Stanley, C.; Behling, C. Prevalence of Fatty Liver in Children and Adolescents. Pediatrics 2006, 118, 1388-1393. [CrossRef]

8. Younossi, Z.M.; Noureddin, M.; Bernstein, D.; Kwo, P.; Russo, M.; Shiffman, M.L.; Younes, Z.; Abdelmalek, M. Role of Noninvasive Tests in Clinical Gastroenterology Practices to Identify Patients With Nonalcoholic Steatohepatitis at High Risk of Adverse Outcomes: Expert Panel Recommendations. Am. J. Gastroenterol. 2021, 116, 254-262. [CrossRef] [PubMed]

9. Setiawan, V.W.; Stram, D.O.; Porcel, J.; Lu, S.C.; Le Marchand, L.; Noureddin, M. Prevalence of Chronic Liver Disease and Cirrhosis by Underlying Cause in Understudied Ethnic Groups: The Multiethnic Cohort. Hepatology 2016, 64, 1969-1977. [CrossRef] [PubMed]

10. Mohamad, B.; Shah, V.; Onyshchenko, M.; Elshamy, M.; Aucejo, F.; Lopez, R.; Hanouneh, I.A.; Alhaddad, R.; Alkhouri, N. Characterization of Hepatocellular Carcinoma (HCC) in Non-Alcoholic Fatty Liver Disease (NAFLD) Patients without Cirrhosis. Hepatol. Int. 2016, 10, 632-639. [CrossRef]

11. Groselj, U.; Tansek, M.Z.; Smon, A.; Angelkova, N.; Anton, D.; Baric, I.; Djordjevic, M.; Grimci, L.; Ivanova, M.; Kadam, A.; et al. Newborn Screening in Southeastern Europe. Mol. Genet. Metab. 2014, 113, 42-45. [CrossRef] [PubMed]

12. Zerjav Tansek, M.; Groselj, U.; Angelkova, N.; Anton, D.; Baric, I.; Djordjevic, M.; Grimci, L.; Ivanova, M.; Kadam, A.; Kotori, V.; et al. Phenylketonuria Screening and Management in Southeastern Europe - Survey Results from 11 Countries. Orphanet J. Rare Dis. 2015, 10, 68. [CrossRef] [PubMed]

13. Feldstein, A.E.; Charatcharoenwitthaya, P.; Treeprasertsuk, S.; Benson, J.T.; Enders, F.B.; Angulo, P. The Natural History of Non-Alcoholic Fatty Liver Disease in Children: A Follow-up Study for up to 20 Years. Gut 2009, 58, 1538-1544. [CrossRef] [PubMed]

14. Chalasani, N.; Younossi, Z.; Lavine, J.E.; Charlton, M.; Cusi, K.; Rinella, M.; Harrison, S.A.; Brunt, E.M.; Sanyal, A.J. The Diagnosis and Management of Nonalcoholic Fatty Liver Disease: Practice Guidance from the American Association for the Study of Liver Diseases. Hepatology 2018, 67, 328-357. [CrossRef] [PubMed]

15. Sterling, R.K.; Lissen, E.; Clumeck, N.; Sola, R.; Correa, M.C.; Montaner, J.; S Sulkowski, M.; Torriani, F.J.; Dieterich, D.T.; Thomas, D.L.; et al. Development of a Simple Noninvasive Index to Predict Significant Fibrosis in Patients with HIV/HCV Coinfection. Hepatology 2006, 43, 1317-1325. [CrossRef] [PubMed]

16. Vilar-Gomez, E.; Chalasani, N. Non-Invasive Assessment of Non-Alcoholic Fatty Liver Disease: Clinical Prediction Rules and Blood-Based Biomarkers. J. Hepatol. 2018, 68, 305-315. [CrossRef]

17. Anstee, Q.M.; Lawitz, E.J.; Alkhouri, N.; Wong, V.W.-S.; Romero-Gomez, M.; Okanoue, T.; Trauner, M.; Kersey, K.; Li, G.; Han, L.; et al. Noninvasive Tests Accurately Identify Advanced Fibrosis Due to NASH: Baseline Data From the STELLAR Trials. Hepatology 2019, 70, 1521-1530. [CrossRef]

18. Cho, Y.; Tokuhara, D.; Morikawa, H.; Kuwae, Y.; Hayashi, E.; Hirose, M.; Hamazaki, T.; Tanaka, A.; Kawamura, T.; Kawada, N.; et al. Transient Elastography-Based Liver Profiles in a Hospital-Based Pediatric Population in Japan. PLoS ONE 2015, 10, e0137239. [CrossRef]

19. Mărginean, C.O.; Meliț, L.E.; Ghiga, D.V.; Săsăran, M.O. The Assessment of Liver Fibrosis in Children with Obesity on Two Methods: Transient and Two Dimensional Shear Wave Elastography. Sci. Rep. 2019, 9, 19800. [CrossRef]

20. Younossi, Z.M.; Koenig, A.B.; Abdelatif, D.; Fazel, Y.; Henry, L.; Wymer, M. Global Epidemiology of Nonalcoholic Fatty Liver Disease-Meta-Analytic Assessment of Prevalence, Incidence, and Outcomes. Hepatology 2016, 64, 73-84. [CrossRef]

21. Byrne, C.D.; Targher, G. NAFLD: A Multisystem Disease. J. Hepatol. 2015, 62, S47-S64. [CrossRef]

22. Younossi, Z.M.; Stepanova, M.; Afendy, M.; Fang, Y.; Younossi, Y.; Mir, H.; Srishord, M. Changes in the Prevalence of the Most Common Causes of Chronic Liver Diseases in the United States from 1988 to 2008. Clin. Gastroenterol. Hepatol. 2011, 9, 524-530.e1; quiz e60. [CrossRef] [PubMed]

23. Ting, Y.-W.; Wong, S.-W.; Anuar Zaini, A.; Mohamed, R.; Jalaludin, M.Y. Metabolic Syndrome Is Associated With Advanced Liver Fibrosis Among Pediatric Patients With Non-Alcoholic Fatty Liver Disease. Front Pediatr. 2019, 7, 491. [CrossRef] [PubMed]

24. Stål, P. Liver Fibrosis in Non-Alcoholic Fatty Liver Disease - Diagnostic Challenge with Prognostic Significance. World J. Gastroenterol. 2015, 21, 11077-11087. [CrossRef] [PubMed]

25. Hoodeshenas, S.; Yin, M.; Venkatesh, S.K. Magnetic Resonance Elastography of Liver: Current Update. Top Magn. Reson. Imaging 2018, 27, 319-333. [CrossRef]

26. Serai, S.D.; Trout, A.T.; Sirlin, C.B. Elastography to Assess the Stage of Liver Fibrosis in Children: Concepts, Opportunities, and Challenges. Clin. Liver Dis. (Hoboken) 2017, 9, 5-10. [CrossRef]

27. DiPaola, F.W.; Schumacher, K.R.; Goldberg, C.S.; Friedland-Little, J.; Parameswaran, A.; Dillman, J.R. Effect of Fontan Operation on Liver Stiffness in Children with Single Ventricle Physiology. Eur. Radiol. 2017, 27, 2434-2442. [CrossRef]

28. Barr, R.G.; Ferraioli, G.; Palmeri, M.L.; Goodman, Z.D.; Garcia-Tsao, G.; Rubin, J.; Garra, B.; Myers, R.P.; Wilson, S.R.; Rubens, D.; et al. Elastography Assessment of Liver Fibrosis: Society of Radiologists in Ultrasound Consensus Conference Statement. Radiology 2015, 276, 845-861. [CrossRef] 
29. Hanquinet, S.; Rougemont, A.-L.; Courvoisier, D.; Rubbia-Brandt, L.; McLin, V.; Tempia, M.; Anooshiravani, M. Acoustic Radiation Force Impulse (ARFI) Elastography for the Noninvasive Diagnosis of Liver Fibrosis in Children. Pediatr. Radiol. 2013, 43, 545-551. [CrossRef]

30. Samir, A.E.; Dhyani, M.; Vij, A.; Bhan, A.K.; Halpern, E.F.; Méndez-Navarro, J.; Corey, K.E.; Chung, R.T. Shear-Wave Elastography for the Estimation of Liver Fibrosis in Chronic Liver Disease: Determining Accuracy and Ideal Site for Measurement. Radiology 2015, 274, 888-896. [CrossRef]

31. Dhyani, M.; Anvari, A.; Samir, A.E. Ultrasound Elastography: Liver. Abdom. Imaging 2015, 40, 698-708. [CrossRef]

32. Venkatesh, S.K.; Ehman, R.L. Magnetic Resonance Elastography of Abdomen. Abdom. Imaging 2015, 40, 745-759. [CrossRef] [PubMed]

33. Sawh, M.C.; Newton, K.P.; Goyal, N.P.; Angeles, J.E.; Harlow, K.; Bross, C.; Schlein, A.N.; Hooker, J.C.; Sy, E.Z.; Glaser, K.J.; et al. Normal Range for MR Elastography Measured Liver Stiffness in Children without Liver Disease. J. Magn. Reson. Imaging 2020, 51, 919-927. [CrossRef] [PubMed]

34. Trout, A.T.; Anupindi, S.A.; Gee, M.S.; Khanna, G.; Xanthakos, S.A.; Serai, S.D.; Baikpour, M.; Calle-Toro, J.S.; Ozturk, A.; Zhang, B.; et al. Normal Liver Stiffness Measured with MR Elastography in Children. Radiology 2020, 297, 663-669. [CrossRef] [PubMed]

35. Berzigotti, A.; Ferraioli, G.; Bota, S.; Gilja, O.H.; Dietrich, C.F. Novel Ultrasound-Based Methods to Assess Liver Disease: The Game Has Just Begun. Dig. Liver Dis. 2018, 50, 107-112. [CrossRef]

36. Serai, S.D.; Wallihan, D.B.; Venkatesh, S.K.; Ehman, R.L.; Campbell, K.M.; Sticka, J.; Marino, B.S.; Podberesky, D.J. Magnetic Resonance Elastography of the Liver in Patients Status-Post Fontan Procedure: Feasibility and Preliminary Results. Congenit. Heart Dis. 2014, 9, 7-14. [CrossRef]

37. Singh, S.; Venkatesh, S.K.; Wang, Z.; Miller, F.H.; Motosugi, U.; Low, R.N.; Hassanein, T.; Asbach, P.; Godfrey, E.M.; Yin, M.; et al. Diagnostic Performance of Magnetic Resonance Elastography in Staging Liver Fibrosis: A Systematic Review and Meta-Analysis of Individual Participant Data. Clin. Gastroenterol. Hepatol. 2015, 13, 440-451.e6. [CrossRef]

38. Besa, C.; Wagner, M.; Lo, G.; Gordic, S.; Chatterji, M.; Kennedy, P.; Stueck, A.; Thung, S.; Babb, J.; Smith, A.; et al. Detection of Liver Fibrosis Using Qualitative and Quantitative MR Elastography Compared to Liver Surface Nodularity Measurement, Gadoxetic Acid Uptake, and Serum Markers. J. Magn. Reson. Imaging 2018, 47, 1552-1561. [CrossRef]

39. Yin, M.; Glaser, K.J.; Talwalkar, J.A.; Chen, J.; Manduca, A.; Ehman, R.L. Hepatic MR Elastography: Clinical Performance in a Series of 1377 Consecutive Examinations. Radiology 2016, 278, 114-124. [CrossRef]

40. Etchell, E.; Jugé, L.; Hatt, A.; Sinkus, R.; Bilston, L.E. Liver Stiffness Values Are Lower in Pediatric Subjects than in Adults and Increase with Age: A Multifrequency MR Elastography Study. Radiology 2017, 283, 222-230. [CrossRef]

41. Yin, M.; Talwalkar, J.A.; Glaser, K.J.; Manduca, A.; Grimm, R.C.; Rossman, P.J.; Fidler, J.L.; Ehman, R.L. Assessment of Hepatic Fibrosis with Magnetic Resonance Elastography. Clin. Gastroenterol. Hepatol. 2007, 5, 1207-1213.e2. [CrossRef]

42. Kim, B.H.; Lee, J.M.; Lee, Y.J.; Lee, K.B.; Suh, K.-S.; Han, J.K.; Choi, B.I. MR Elastography for Noninvasive Assessment of Hepatic Fibrosis: Experience from a Tertiary Center in Asia. J. Magn. Reson. Imaging 2011, 34, 1110-1116. [CrossRef]

43. Venkatesh, S.K.; Wang, G.; Lim, S.G.; Wee, A. Magnetic Resonance Elastography for the Detection and Staging of Liver Fibrosis in Chronic Hepatitis B. Eur. Radiol. 2014, 24, 70-78. [CrossRef] [PubMed]

44. Huwart, L.; Peeters, F.; Sinkus, R.; Annet, L.; Salameh, N.; ter Beek, L.C.; Horsmans, Y.; Van Beers, B.E. Liver Fibrosis: Non-Invasive Assessment with MR Elastography. NMR Biomed. 2006, 19, 173-179. [CrossRef] [PubMed]

45. Chen, J.; Talwalkar, J.A.; Yin, M.; Glaser, K.J.; Sanderson, S.O.; Ehman, R.L. Early Detection of Nonalcoholic Steatohepatitis in Patients with Nonalcoholic Fatty Liver Disease by Using MR Elastography. Radiology 2011, 259, 749-756. [CrossRef] [PubMed]

46. Morisaka, H.; Motosugi, U.; Ichikawa, S.; Nakazawa, T.; Kondo, T.; Funayama, S.; Matsuda, M.; Ichikawa, T.; Onishi, H. Magnetic Resonance Elastography Is as Accurate as Liver Biopsy for Liver Fibrosis Staging. J. Magn. Reson. Imaging 2018, 47, $1268-1275$. [CrossRef] [PubMed]

47. Park, C.C.; Nguyen, P.; Hernandez, C.; Bettencourt, R.; Ramirez, K.; Fortney, L.; Hooker, J.; Sy, E.; Savides, M.T.; Alquiraish, M.H.; et al. Magnetic Resonance Elastography vs Transient Elastography in Detection of Fibrosis and Noninvasive Measurement of Steatosis in Patients With Biopsy-Proven Nonalcoholic Fatty Liver Disease. Gastroenterology 2017, 152, 598-607.e2. [CrossRef]

48. Loomba, R.; Cui, J.; Wolfson, T.; Haufe, W.; Hooker, J.; Szeverenyi, N.; Ang, B.; Bhatt, A.; Wang, K.; Aryafar, H.; et al. Novel 3D Magnetic Resonance Elastography for the Noninvasive Diagnosis of Advanced Fibrosis in NAFLD: A Prospective Study. Am. J. Gastroenterol. 2016, 111, 986-994. [CrossRef] [PubMed]

49. Imajo, K.; Kessoku, T.; Honda, Y.; Tomeno, W.; Ogawa, Y.; Mawatari, H.; Fujita, K.; Yoneda, M.; Taguri, M.; Hyogo, H.; et al Magnetic Resonance Imaging More Accurately Classifies Steatosis and Fibrosis in Patients With Nonalcoholic Fatty Liver Disease Than Transient Elastography. Gastroenterology 2016, 150, 626-637.e7. [CrossRef] [PubMed]

50. Joshi, M.; Dillman, J.R.; Singh, K.; Serai, S.D.; Towbin, A.J.; Xanthakos, S.; Zhang, B.; Su, W.; Trout, A.T. Quantitative MRI of Fatty Liver Disease in a Large Pediatric Cohort: Correlation between Liver Fat Fraction, Stiffness, Volume, and Patient-Specific Factors. Abdom. Radiol. (NY) 2018, 43, 1168-1179. [CrossRef] [PubMed]

51. Venkatesh, K. Clinical Applications of Liver Magnetic Resonance Elastography: Chronic Liver Disease. In Magnetic Resonance Elastography New York; Springer: New York, NY, USA, 2014; pp. 39-60.

52. Kim, D.; Kim, W.R.; Talwalkar, J.A.; Kim, H.J.; Ehman, R.L. Advanced Fibrosis in Nonalcoholic Fatty Liver Disease: Noninvasive Assessment with MR Elastography. Radiology 2013, 268, 411-419. [CrossRef] 
53. Ferraioli, G.; Wong, V.W.-S.; Castera, L.; Berzigotti, A.; Sporea, I.; Dietrich, C.F.; Choi, B.I.; Wilson, S.R.; Kudo, M.; Barr, R.G. Liver Ultrasound Elastography: An Update to the World Federation for Ultrasound in Medicine and Biology Guidelines and Recommendations. Ultrasound Med. Biol 2018, 44, 2419-2440. [CrossRef]

54. Krishnamurthy, R.; Thompson, B.L.; Shankar, A.; Gariepy, C.E.; Potter, C.J.; Fung, B.R.; Hu, H.H. Magnetic Resonance Elastography of the Liver in Children and Adolescents: Assessment of Regional Variations in Stiffness. Acad Radiol. 2020, 27, e109-e115. [CrossRef] [PubMed]

55. Trout, A.T.; Sheridan, R.M.; Serai, S.D.; Xanthakos, S.A.; Su, W.; Zhang, B.; Wallihan, D.B. Diagnostic Performance of MR Elastography for Liver Fibrosis in Children and Young Adults with a Spectrum of Liver Diseases. Radiology 2018, 287, 824-832. [CrossRef]

56. Joshi, M.; Dillman, J.R.; Towbin, A.J.; Serai, S.D.; Trout, A.T. MR Elastography: High Rate of Technical Success in Pediatric and Young Adult Patients. Pediatr. Radiol. 2017, 47, 838-843. [CrossRef] [PubMed]

57. Schwimmer, J.B.; Behling, C.; Angeles, J.E.; Paiz, M.; Durelle, J.; Africa, J.; Newton, K.P.; Brunt, E.M.; Lavine, J.E.; Abrams, S.H.; et al. Magnetic Resonance Elastography Measured Shear Stiffness as a Biomarker of Fibrosis in Pediatric Nonalcoholic Fatty Liver Disease. Hepatology 2017, 66, 1474-1485. [CrossRef] [PubMed]

58. Xanthakos, S.A.; Podberesky, D.J.; Serai, S.D.; Miles, L.; King, E.C.; Balistreri, W.F.; Kohli, R. Use of Magnetic Resonance Elastography to Assess Hepatic Fibrosis in Children with Chronic Liver Disease. J. Pediatr. 2014, 164, 186-188. [CrossRef]

59. Manduca, A.; Oliphant, T.E.; Dresner, M.A.; Mahowald, J.L.; Kruse, S.A.; Amromin, E.; Felmlee, J.P.; Greenleaf, J.F.; Ehman, R.L. Magnetic Resonance Elastography: Non-Invasive Mapping of Tissue Elasticity. Med. Image Anal. 2001, 5, 237-254. [CrossRef]

60. Ferraioli, G.; Barr, R.G.; Dillman, J.R. Elastography for Pediatric Chronic Liver Disease: A Review and Expert Opinion. J. Ultrasound Med. 2020. [CrossRef] [PubMed]

61. Barr, R.G.; Wilson, S.R.; Rubens, D.; Garcia-Tsao, G.; Ferraioli, G. Update to the Society of Radiologists in Ultrasound Liver Elastography Consensus Statement. Radiology 2020, 296, 263-274. [CrossRef] [PubMed]

62. Ferraioli, G.; De Silvestri, A.; Lissandrin, R.; Maiocchi, L.; Tinelli, C.; Filice, C.; Barr, R.G. Evaluation of Inter-System Variability in Liver Stiffness Measurements. Ultraschall Med. 2019, 40, 64-75. [CrossRef] [PubMed]

63. Piscaglia, F.; Salvatore, V.; Mulazzani, L.; Cantisani, V.; Colecchia, A.; Di Donato, R.; Felicani, C.; Ferrarini, A.; Gamal, N.; Grasso, V.; et al. Differences in Liver Stiffness Values Obtained with New Ultrasound Elastography Machines and Fibroscan: A Comparative Study. Dig. Liver Dis. 2017, 49, 802-808. [CrossRef]

64. Li, D.K.; Khan, M.R.; Wang, Z.; Chongsrisawat, V.; Swangsak, P.; Teufel-Schäfer, U.; Engelmann, G.; Goldschmidt, I.; Baumann, U.; Tokuhara, D.; et al. Normal Liver Stiffness and Influencing Factors in Healthy Children: An Individual Participant Data Meta-Analysis. Liver Int. 2020, 40, 2602-2611. [CrossRef] [PubMed]

65. Raizner, A.; Shillingford, N.; Mitchell, P.D.; Harney, S.; Raza, R.; Serino, J.; Jonas, M.M.; Lee, C.K. Hepatic Inflammation May Influence Liver Stiffness Measurements by Transient Elastography in Children and Young Adults. J. Pediatr. Gastroenterol. Nutr. 2017, 64, 512-517. [CrossRef] [PubMed]

66. Wallihan, D.B.; Podberesky, D.J.; Marino, B.S.; Sticka, J.S.; Serai, S. Relationship of MR Elastography Determined Liver Stiffness with Cardiac Function after Fontan Palliation. J. Magn. Reson. Imaging 2014, 40, 1328-1335. [CrossRef] [PubMed]

67. Trout, A.T.; Xanthakos, S.A.; Bennett, P.S.; Dillman, J.R. Liver Shear Wave Speed and Other Quantitative Ultrasound Measures of Liver Parenchyma: Prospective Evaluation in Healthy Children and Adults. AJR Am. J. Roentgenol 2020, 214, 557-565. [CrossRef] [PubMed]

68. Bailey, S.S.; Youssfi, M.; Patel, M.; Hu, H.H.; Shaibi, G.Q.; Towbin, R.B. Shear-Wave Ultrasound Elastography of the Liver in Normal-Weight and Obese Children. Acta Radiol. 2017, 58, 1511-1518. [CrossRef]

69. Fontanilla, T.; Cañas, T.; Macia, A.; Alfageme, M.; Gutierrez Junquera, C.; Malalana, A.; Luz Cilleruelo, M.; Roman, E.; Miralles, M. Normal Values of Liver Shear Wave Velocity in Healthy Children Assessed by Acoustic Radiation Force Impulse Imaging Using a Convex Probe and a Linear Probe. Ultrasound Med. Biol. 2014, 40, 470-477. [CrossRef]

70. Matos, H.; Trindade, A.; Noruegas, M.J. Acoustic Radiation Force Impulse Imaging in Paediatric Patients: Normal Liver Values. J. Pediatr. Gastroenterol. Nutr. 2014, 59, 684-688. [CrossRef]

71. Pauleau, G.; Sandoz, B.; Thollon, L.; Serre, T.; Brunet, C. Anthropometric Characterization of the Child Liver. Surg. Radiol. Anat. 2010, 32, 767-775. [CrossRef]

72. Yarpuzlu, B.; Ayyildiz, M.; Tok, O.E.; Aktas, R.G.; Basdogan, C. Correlation between the Mechanical and Histological Properties of Liver Tissue. J. Mech. Behav. Biomed. Mater. 2014, 29, 403-416. [CrossRef] [PubMed]

73. Tokuhara, D.; Cho, Y.; Shintaku, H. Transient Elastography-Based Liver Stiffness Age-Dependently Increases in Children. PLoS ONE 2016, 11, e0166683. [CrossRef]

74. Mărginean, C.O.; Meliţ, L.E.; Ghiga, D.V.; Săsăran, M.O. Reference Values of Normal Liver Stiffness in Healthy Children by Two Methods: 2D Shear Wave and Transient Elastography. Sci. Rep. 2020, 10, 7213. [CrossRef]

75. Goldschmidt, I.; Streckenbach, C.; Dingemann, C.; Pfister, E.D.; di Nanni, A.; Zapf, A.; Baumann, U. Application and Limitations of Transient Liver Elastography in Children. J. Pediatr. Gastroenterol. Nutr. 2013, 57, 109-113. [CrossRef] [PubMed]

76. Mjelle, A.B.; Mulabecirovic, A.; Havre, R.F.; Rosendahl, K.; Juliusson, P.B.; Olafsdottir, E.; Gilja, O.H.; Vesterhus, M. Normal Liver Stiffness Values in Children: A Comparison of Three Different Elastography Methods. J. Pediatr. Gastroenterol. Nutr. 2019, 68, 706-712. [CrossRef] 
77. Galina, P.; Alexopoulou, E.; Zellos, A.; Grigoraki, V.; Siahanidou, T.; Kelekis, N.L.; Zarifi, M. Performance of Two-Dimensional Ultrasound Shear Wave Elastography: Reference Values of Normal Liver Stiffness in Children. Pediatr. Radiol. 2019, 49, 91-98. [CrossRef]

78. Özkan, M.B.; Bilgici, M.C.; Eren, E.; Caltepe, G.; Yilmaz, G.; Kara, C.; Gun, S. Role of Point Shear Wave Elastography in the Determination of the Severity of Fibrosis in Pediatric Liver Diseases With Pathologic Correlations. J. Ultrasound Med. 2017, 36, 2337-2344. [CrossRef]

79. Franchi-Abella, S.; Corno, L.; Gonzales, E.; Antoni, G.; Fabre, M.; Ducot, B.; Pariente, D.; Gennisson, J.-L.; Tanter, M.; Corréas, J.-M. Feasibility and Diagnostic Accuracy of Supersonic Shear-Wave Elastography for the Assessment of Liver Stiffness and Liver Fibrosis in Children: A Pilot Study of 96 Patients. Radiology 2016, 278, 554-562. [CrossRef]

80. Lewindon, P.J.; Balouch, F.; Pereira, T.N.; Puertolas-Lopez, M.V.; Noble, C.; Wixey, J.A.; Ramm, G.A. Transient Liver Elastography in Unsedated Control Children: Impact of Age and Intercurrent Illness. J. Paediatr. Child Health 2016, 52, 637-642. [CrossRef] [PubMed]

81. Tutar, O.; Beşer, Ö.F.; Adaletli, I.; Tunc, N.; Gulcu, D.; Kantarci, F.; Mihmanli, I.; Cokugras, F.C.; Kutlu, T.; Ozbay, G.; et al. Shear Wave Elastography in the Evaluation of Liver Fibrosis in Children. J. Pediatr. Gastroenterol. Nutr. 2014, 58, 750-755. [CrossRef] [PubMed]

82. Honsawek, S.; Vejchapipat, P.; Payungporn, S.; Theamboonlers, A.; Chongsrisawat, V.; Poovorawan, Y. Soluble Receptor for Advanced Glycation End Products and Liver Stiffness in Postoperative Biliary Atresia. Clin. Biochem. 2013, 46, 214-218. [CrossRef] [PubMed]

83. Hanquinet, S.; Courvoisier, D.; Kanavaki, A.; Dhouib, A.; Anooshiravani, M. Acoustic Radiation Force Impulse Imaging-Normal Values of Liver Stiffness in Healthy Children. Pediatr. Radiol. 2013, 43, 539-544. [CrossRef]

84. Lee, M.-J.; Kim, M.-J.; Han, K.H.; Yoon, C.S. Age-Related Changes in Liver, Kidney, and Spleen Stiffness in Healthy Children Measured with Acoustic Radiation Force Impulse Imaging. Eur. J. Radiol. 2013, 82, e290-e294. [CrossRef]

85. Marginean, C.O.; Marginean, C. Elastographic Assessment of Liver Fibrosis in Children: A Prospective Single Center Experience. Eur. J. Radiol. 2012, 81, e870-e874. [CrossRef]

86. Noruegas, M.J.; Matos, H.; Gonçalves, I.; Cipriano, M.A.; Sanches, C. Acoustic Radiation Force Impulse-Imaging in the Assessment of Liver Fibrosis in Children. Pediatr. Radiol. 2012, 42, 201-204. [CrossRef] [PubMed]

87. Engelmann, G.; Gebhardt, C.; Wenning, D.; Wühl, E.; Hoffmann, G.F.; Selmi, B.; Grulich-Henn, J.; Schenk, J.P.; Teufel, U. Feasibility Study and Control Values of Transient Elastography in Healthy Children. Eur. J. Pediatr. 2012, 171, 353-360. [CrossRef]

88. Eiler, J.; Kleinholdermann, U.; Albers, D.; Dahms, J.; Hermann, F.; Behrens, C.; Luedemann, M.; Klingmueller, V.; Alzen, G.F.P. Standard Value of Ultrasound Elastography Using Acoustic Radiation Force Impulse Imaging (ARFI) in Healthy Liver Tissue of Children and Adolescents. Ultraschall Med. 2012, 33, 474-479. [CrossRef] [PubMed]

89. Menten, R.; Leonard, A.; Clapuyt, P.; Vincke, P.; Nicolae, A.-C.; Lebecque, P. Transient Elastography in Patients with Cystic Fibrosis. Pediatr. Radiol. 2010, 40, 1231-1235. [CrossRef] [PubMed]

90. Witters, P.; De Boeck, K.; Dupont, L.; Proesmans, M.; Vermeulen, F.; Servaes, R.; Verslype, C.; Laleman, W.; Nevens, F.; Hoffman, I.; et al. Non-Invasive Liver Elastography (Fibroscan) for Detection of Cystic Fibrosis-Associated Liver Disease. J. Cyst. Fibros. 2009, 8, 392-399. [CrossRef]

91. Rubio, A.; Monpoux, F.; Huguon, E.; Truchi, R.; Triolo, V.; Rosenthal-Allieri, M.-A.; Deville, A.; Rosenthal, E.; Boutté, P.; Tran, A. Noninvasive Procedures to Evaluate Liver Involvement in HIV-1 Vertically Infected Children. J. Pediatr. Gastroenterol. Nutr. 2009, 49, 599-606. [CrossRef]

92. Francavilla, R.; Cecinati, V.; Bucci, N.; Castellaneta, S.; Brescia, L.; Barone, M.; Indrio, F.; Cavallo, L. Normal Values of Transient Elastography (Fibroscan) in Children without Evidence of Liver Disease: Comparison of Adult versus Paediatric Probe. Dig. Liver Dis. 2008, 40, A61. [CrossRef]

93. Giuffrè, M.; Fouraki, S.; Comar, M.; Masutti, F.; Crocè, L.S. The Importance of Transaminases Flare in Liver Elastography: Characterization of the Probability of Liver Fibrosis Overestimation by Hepatitis C Virus-Induced Cytolysis. Microorganisms 2020, 8, 348. [CrossRef] [PubMed]

94. Popescu, A.; Bota, S.; Sporea, I.; Sirli, R.; Danila, M.; Racean, S.; Suseanu, D.; Gradinaru, O.; Ivascu Siegfried, C. The Influence of Food Intake on Liver Stiffness Values Assessed by Acoustic Radiation Force Impulse Elastography-Preliminary Results. Ultrasound Med. Biol. 2013, 39, 579-584. [CrossRef] [PubMed]

95. Yin, M.; Talwalkar, J.A.; Glaser, K.J.; Venkatesh, S.K.; Chen, J.; Manduca, A.; Ehman, R.L. Dynamic Postprandial Hepatic Stiffness Augmentation Assessed with MR Elastography in Patients with Chronic Liver Disease. AJR Am. J. Roentgenol. 2011, 197, 64-70. [CrossRef] [PubMed]

96. Roccarina, D.; Rosselli, M.; Genesca, J.; Tsochatzis, E.A. Elastography Methods for the Non-Invasive Assessment of Portal Hypertension. Expert Rev. Gastroenterol. Hepatol. 2018, 12, 155-164. [CrossRef]

97. Giuffrè, M.; Fouraki, S.; Campigotto, M.; Colombo, A.; Visintin, A.; Buonocore, M.R.; Aversano, A.; Budel, M.; Tinè, F.; Abazia, C.; et al. Alanine Aminotransferase and Spleno-Portal Dynamics Affect Spleen Stiffness Measured by Point Shear-Wave Elastography in Patients with Chronic Hepatitis C in the Absence of Significant Liver Fibrosis. J. Ultrasound 2021, 24, 67-73. [CrossRef]

98. Varbobitis, I.C.; Siakavellas, S.I.; Koutsounas, I.S.; Karagiannakis, D.S.; Ioannidou, P.; Papageorgiou, M.-V.; Pavlopoulou, I.D.; Schizas, D.; Bamias, G.; Vlachogiannakos, I.; et al. Reliability and Applicability of Two-Dimensional Shear-Wave Elastography for the Evaluation of Liver Stiffness. Eur. J. Gastroenterol. Hepatol. 2016, 28, 1204-1209. [CrossRef] 
99. Nobili, V.; Vizzutti, F.; Arena, U.; Abraldes, J.G.; Marra, F.; Pietrobattista, A.; Fruhwirth, R.; Marcellini, M.; Pinzani, M. Accuracy and Reproducibility of Transient Elastography for the Diagnosis of Fibrosis in Pediatric Nonalcoholic Steatohepatitis. Hepatology 2008, 48, 442-448. [CrossRef]

100. Karlas, T.; Dietrich, A.; Peter, V.; Wittekind, C.; Lichtinghagen, R.; Garnov, N.; Linder, N.; Schaudinn, A.; Busse, H.; Prettin, C.; et al. Evaluation of Transient Elastography, Acoustic Radiation Force Impulse Imaging (ARFI), and Enhanced Liver Function (ELF) Score for Detection of Fibrosis in Morbidly Obese Patients. PLoS ONE 2015, 10, e0141649. [CrossRef]

101. Jiang, W.; Huang, S.; Teng, H.; Wang, P.; Wu, M.; Zhou, X.; Ran, H. Diagnostic Accuracy of Point Shear Wave Elastography and Transient Elastography for Staging Hepatic Fibrosis in Patients with Non-Alcoholic Fatty Liver Disease: A Meta-Analysis. BMJ. Open 2018, 8, e021787. [CrossRef]

102. Myers, R.P.; Pomier-Layrargues, G.; Kirsch, R.; Pollett, A.; Duarte-Rojo, A.; Wong, D.; Beaton, M.; Levstik, M.; Crotty, P.; Elkashab, M. Feasibility and Diagnostic Performance of the FibroScan XL Probe for Liver Stiffness Measurement in Overweight and Obese Patients. Hepatology 2012, 55, 199-208. [CrossRef]

103. Giuffrè, M.; Giuricin, M.; Bonazza, D.; Rosso, N.; Giraudi, P.J.; Masutti, F.; Palmucci, S.; Basile, A.; Zanconati, F.; de Manzini, N.; et al. Optimization of Point-Shear Wave Elastography by Skin-to-Liver Distance to Assess Liver Fibrosis in Patients Undergoing Bariatric Surgery. Diagnostics (Basel) 2020, 10, 795. [CrossRef]

104. Su, S.; Wang, W.; Nadebaum, D.; Nicoll, A.; Sood, S.; Gorelik, A.; Lai, J.; Gibson, R. Skin-Liver Distance and Interquartile Range-Median Ratio as Determinants of Interoperator Concordance in Acoustic Radiation Force Impulse Imaging. J. Med. Ultrasound 2019, 27, 177-180. [CrossRef] [PubMed]

105. Nadebaum, D.; Gibson, R.; Howell, J.; Halliday, J.; Christie, M.; Gorelik, A.; Gib, A. Inter-Operator Concordance in Acoustic Radiation Force Impulse Imaging (ARFI): A Practical Role for Multiple Operators to Improve Diagnostic Performance. J. Gastroenterol. Hepatol. Hepatol. Clin. Abstr. 2014, 29, 68-101.

106. Shen, F.; Zheng, R.-D.; Shi, J.-P.; Mi, Y.-Q.; Chen, G.-F.; Hu, X.; Liu, Y.-G.; Wang, X.-Y.; Pan, Q.; Chen, G.-Y.; et al. Impact of Skin Capsular Distance on the Performance of Controlled Attenuation Parameter in Patients with Chronic Liver Disease. Liver Int. 2015, 35, 2392-2400. [CrossRef] [PubMed]

107. Andersen, S.B.; Ewertsen, C.; Carlsen, J.F.; Henriksen, B.M.; Nielsen, M.B. Ultrasound Elastography Is Useful for Evaluation of Liver Fibrosis in Children-A Systematic Review. J. Pediatr. Gastroenterol. Nutr. 2016, 63, 389-399. [CrossRef] [PubMed]

108. Nobili, V.; Monti, L.; Alisi, A.; Lo Zupone, C.; Pietrobattista, A.; Tomà, P. Transient Elastography for Assessment of Fibrosis in Paediatric Liver Disease. Pediatr. Radiol. 2011, 41, 1232-1238. [CrossRef]

109. Kamble, R.; Sodhi, K.S.; Thapa, B.R.; Saxena, A.K.; Bhatia, A.; Dayal, D.; Khandelwal, N. Liver Acoustic Radiation Force Impulse (ARFI) in Childhood Obesity: Comparison and Correlation with Biochemical Markers. J. Ultrasound 2017, 20, 33-42. [CrossRef]

110. Kim, J.R.; Suh, C.H.; Yoon, H.M.; Lee, J.S.; Cho, Y.A.; Jung, A.Y. The Diagnostic Performance of Shear-Wave Elastography for Liver Fibrosis in Children and Adolescents: A Systematic Review and Diagnostic Meta-Analysis. Eur. Radiol. 2018, 28, 1175-1186. [CrossRef]

111. Sagir, A.; Ney, D.; Oh, J.; Pandey, S.; Kircheis, G.; Mayatepek, E.; Häussinger, D. Evaluation of Acoustic Radiation Force Impulse Imaging (ARFI) for the Determination of Liver Stiffness Using Transient Elastography as a Reference in Children. Ultrasound Int. Open 2015, 1, E2-E7. [CrossRef]

112. Garcovich, M.; Veraldi, S.; Di Stasio, E.; Zocco, M.A.; Monti, L.; Tomà, P.; Pompili, M.; Gasbarrini, A.; Nobili, V. Liver Stiffness in Pediatric Patients with Fatty Liver Disease: Diagnostic Accuracy and Reproducibility of Shear-Wave Elastography. Radiology 2017, 283, 820-827. [CrossRef]

113. Lee, M.S.; Bae, J.M.; Joo, S.K.; Woo, H.; Lee, D.H.; Jung, Y.J.; Kim, B.G.; Lee, K.L.; Kim, W. Prospective Comparison among Transient Elastography, Supersonic Shear Imaging, and ARFI Imaging for Predicting Fibrosis in Nonalcoholic Fatty Liver Disease. PLoS ONE 2017, 12, e0188321. [CrossRef] [PubMed]

114. Angulo, P.; Kleiner, D.E.; Dam-Larsen, S.; Adams, L.A.; Bjornsson, E.S.; Charatcharoenwitthaya, P.; Mills, P.R.; Keach, J.C.; Lafferty, H.D.; Stahler, A.; et al. Liver Fibrosis, but No Other Histologic Features, Is Associated With Long-Term Outcomes of Patients With Nonalcoholic Fatty Liver Disease. Gastroenterology 2015, 149, 389-397.E10. [CrossRef] [PubMed]

115. Alkhouri, N.; Sedki, E.; Alisi, A.; Lopez, R.; Pinzani, M.; Feldstein, A.E.; Nobili, V. Combined Paediatric NAFLD Fibrosis Index and Transient Elastography to Predict Clinically Significant Fibrosis in Children with Fatty Liver Disease. Liver Int. 2013, 33, 79-85. [CrossRef] [PubMed]

116. Brunt, E.M.; Janney, C.G.; Di Bisceglie, A.M.; Neuschwander-Tetri, B.A.; Bacon, B.R. Nonalcoholic Steatohepatitis: A Proposal for Grading and Staging the Histological Lesions. Am. J. Gastroenterol. 1999, 94, 2467-2474. [CrossRef] [PubMed]

117. Kleiner, D.E.; Brunt, E.M.; Van Natta, M.; Behling, C.; Contos, M.J.; Cummings, O.W.; Ferrell, L.D.; Liu, Y.-C.; Torbenson, M.S.; Unalp-Arida, A.; et al. Design and Validation of a Histological Scoring System for Nonalcoholic Fatty Liver Disease. Hepatology 2005, 41, 1313-1321. [CrossRef] [PubMed]

118. Hwang, J.-Y.; Yoon, H.M.; Kim, J.R.; Lee, J.S.; Jung, A.Y.; Kim, K.M.; Cho, Y.A. Diagnostic Performance of Transient Elastography for Liver Fibrosis in Children: A Systematic Review and Meta-Analysis. AJR Am. J. Roentgenol. 2018, 211, W257-W266. [CrossRef] [PubMed]

119. Hamaguchi, M.; Kojima, T.; Itoh, Y.; Harano, Y.; Fujii, K.; Nakajima, T.; Kato, T.; Takeda, N.; Okuda, J.; Ida, K.; et al. The Severity of Ultrasonographic Findings in Nonalcoholic Fatty Liver Disease Reflects the Metabolic Syndrome and Visceral Fat Accumulation. Am. J. Gastroenterol. 2007, 102, 2708-2715. [CrossRef] [PubMed] 
120. Berná-Serna, J.D.; Sánchez-Jiménez, R.; Velázquez-Marín, F.; Sainz de Baranda, P.; Guzmán-Aroca, F.; Fernández-Hernández, C.; Doménech-Abellán, E.; Abellán-Rivero, D.; Ruiz-Merino, G.; Madrid-Conesa, J.; et al. Acoustic Radiation Force Impulse Imaging for Detection of Liver Fibrosis in Overweight and Obese Children. Acta Radiol. 2018, 59, 247-253. [CrossRef] [PubMed]

121. Hudert, C.A.; Tzschätzsch, H.; Guo, J.; Rudolph, B.; Bläker, H.; Loddenkemper, C.; Luck, W.; Müller, H.-P.; Baumgart, D.C.; Hamm, B.; et al. US Time-Harmonic Elastography: Detection of Liver Fibrosis in Adolescents with Extreme Obesity with Nonalcoholic Fatty Liver Disease. Radiology 2018, 288, 99-106. [CrossRef]

122. Fitzpatrick, E.; Quaglia, A.; Vimalesvaran, S.; Basso, M.S.; Dhawan, A. Transient Elastography Is a Useful Noninvasive Tool for the Evaluation of Fibrosis in Paediatric Chronic Liver Disease. J. Pediatr. Gastroenterol. Nutr. 2013, 56, 72-76. [CrossRef] 